- YEARBBOOK of ANTITRUST and REGULATORY STUDIES www.yars.wz.uw.edu.pl
Peer-reviewe $\bar{d}$ scientific $\overline{p e r i o d i c a l,}$ focusing on legal and economic issues of antitrust and regulation. Creative Commons Attribution-No Derivative Works 3.0 Poland License.

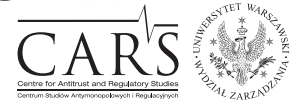

Centre for Antitrust and Regulatory Studies, University of Warsaw, Faculty of Management www.cars.wZ.uw.edu.pl

\title{
Marketplaces Restrictions and Selective Distribution after Coty Germany
}

\author{
by
}

\author{
Patrycja Szot and Ana Amza*
}

\section{CONTENTS}

I. Introduction

II. Facts of Coty Germany

III. Marketplace bans are not by object restrictions

1. Coty's platform ban does not restrict passive sales or retailer's customer group

2. Platform bans should be assessed based on the 'by effect' approach and may benefit from exemptions

3. Is a platform ban a hardcore restriction if applied in relation to non-luxury goods?

4. The relevance of search engines and online advertising

5. Risk of diverging approaches to exemptions

IV. The luxury of being a luxury

1. Legitimate nature of selective distribution and platform bans designed to preserve the luxury image of contract goods

1.1. Metro Conditions

1.2. The rationale behind the protection of the image of luxury goods

2. Practical implications

2.1. Protection of the image of a luxury good is a legitimate objective

2.2. Simplified verification track for luxury goods

2.3. Recourse to exemptions (mixed systems, goods with unclear status)

2.4. The brands at the beginning of their market circle and 'commonized' brands

* Patrycja Szot, LL.M., PhD, Warsaw Bar; e-mail: p.szot@lawyer-competition.eu; Ana Amza, LL.M.; e-mail: anna.amza@yahoo.com. All views expressed in this article are strictly personal. Article received: 16 July 2018; accepted: 24 September 2018. 
3. How to define 'luxury'?

4. Are selective distribution and platform bans designed to preserve the image of non-luxury products outside of Article 101 TFEU?

V. Pros and Cons of platform bans

1. Price transparency v. free-riding

2. Aggregation of consumer demand

3. Access to the market and cross border trade

VI. Price comparison tools

1. PCT Pros and Cons

2. The Commission's stance concerning PCTs ban

3. Practical implications

VII. National examples

1. German Competition Authority cases

1.1. Adidas Decision (sportswear)

1.2. ASICS Decision (running shoes)

2. Other German Cases

2.1. School Bags cases

2.2. Functional Backpacks (Deuter)

3. Dutch Nike Case

4. French cases

VIII. Conclusions

\section{Abstract}

This article discusses the framework of selective distribution agreements within EU competition law following the Coty Germany case and the EU Commission's 2017 E-commerce report. It argues that the judgment removed, in essence, the limitation of sales via online platforms from the 'by object box'. In respect of luxury goods, the ban is considered not to infringe competition law at all. In this context, the article addresses one of the judgment's key points: what constitutes a 'luxury good' and evaluates to what an extent this definition can be practically applied. The authors also embark on the conditions under which the restriction is considered proportionate (when applied to non-luxury goods) and point to the risk of divergent interpretations of platform bans across member states. To illustrate the latter, several examples are given from national case-law. The considerations are completed with a brief look at problematic restrictions on the use of price comparison tools.

\section{Résumé}

Cet article traite de la distribution sélective dans le cadre de la législation européenne sur la concurrence suite au jugement Coty Germany et au rapport de la Commission Européenne sur le e-commerce datant de 2017. De l'avis des auteurs, ce jugement a exclu de la catégorie «restrictions par objet» la limitation 
des ventes sur des plateformes tierces. Par contre, en ce qui concerne les produits de luxe, cette restriction n'est pas considérée comme une violation du droit de la concurrence. Dans ce contexte, l'article aborde l'un des points clés du jugement: la définition legale d'un produit de luxe, et évalue dans quelle mesure cette définition est applicable en pratique. Les auteurs s'intéressent également aux conditions sous lesquelles la restriction des ventes sur des plateformes tierces (pour les produits non luxueux) est considérée proportionnée et soulignent le risque d'interprétations divergentes au sein des états membres. Pour illustrer ce point, plusieurs exemples tirés de la jurisprudence nationale sont donnés. Larticle aborde enfin brièvement les problèmes de restrictions relatives aux comparateurs de prix en ligne.

Key words: Coty; platform ban; selective distribution; distribution of luxury goods; distribution of branded goods; restriction of online sales; e-commerce; restriction on passive sales; price comparison tools; marketplace restriction.

JEL: K21

\section{Introduction}

The development of the Internet, and the increasing switch of consumers from shopping in brick and mortar shops to virtual ones, was bound to raise issues in a variety of fields, not least of which competition law. Coty Germany ${ }^{1}$ is one of the cases which promised to clarify the position of selective distribution agreements in the era of modern e-commerce, an issue that figures highly on the agenda of the European Commission as well as national competition authorities. By looking at theoretical concepts in a practical fashion, this paper aims to facilitate a proper understanding of the implications of Coty Germany in the context of current developments. It invites, therefore, the reader to ponder upon recurring issues such as legality of platform bans or other e-commerce related restrictions, that is, the use of price comparison tools in selective distribution, how to identify/define luxury products, and how this classification is bound to impact restrictions included in selective distribution.

The above concepts are discussed in the next paragraphs of this article in the following order. After a brief introduction to the facts of Coty Germany, the authors proceed to analyse what in their perspective represents the most significant aspects of the judgment in the context of e-tailing. Firstly, the effects approach to marketplace bans proposed in Coty Germany is discussed.

\footnotetext{
1 Judgement of 6.12.2017, Case C-230/16 Coty Germany GmbH v Parfümerie Akzente GmbH, ECLI:EU:C:2017:941
} 
Secondly, the scope of the complete 'exemption' provided for luxury goods and the definition of the latter is considered. Thirdly, the authors reflect on arguments in favour and against platform bans. Fourthly, the position of other restraints such as a restriction on the use of price comparison tools (hereinafter; PCT) is briefly analysed. Lastly, the authors discuss several examples of national cases relating to platform and PCT bans and conclude with closing remarks.

In the authors' view, the ruling effectively removed the restrictions on sales via online platforms from the 'restriction by object box', irrespective of the nature of the goods concerned. Hence, such restrictions may benefit from exemptions. In the context of selective distribution of luxury goods, the CJEU went further and decided that a platform ban is outside the scope of Article 101 TFEU. The ruling also ended the discussion on whether the protection of a luxury image can be a legitimate objective of selective distribution (and platform bans), and reaffirmed the CJEU's harsh position on limitations of online advertising, including by the use of price comparison tools. Nonetheless, businesses will continue to face uncertainties concerning the use of platform bans and other e-commerce related restrictions within the framework of selective distribution. The primary reason behind this conclusion is that national authorities and courts may continue to assign different weights to arguments relating to those restrictions based on diverse interpretation of facts (for example, if the given good is luxury or when defining product markets) or expected effects of the constraint under examination. The brief overview of national case law predating and from the time of Coty Germany and findings of the EU Commission's (hereinafter; Commission) recent survey on E-commerce, only reaffirm this supposition. The Commission will need to reflect on these developments and challenges in upcoming review of its guidelines on vertical restraints.

\section{Facts of Coty Germany}

Coty Germany (hereinafter; Coty) sells luxury cosmetics through a selective distribution system (hereinafter; SDS). 'The sales locations of its authorised distributors must comply with a number of requirements relating to their environment, décor and furnishing.' 2 The aim of this requirement and similar standards imposed in relation to the selection and presentation of goods and advertising was to highlight and preserve the luxury status of Coty's products.

2 See Press Release No. 132/17 on Coty Germany retrieved from https://curia.europa.eu/ jcms/upload/docs/application/pdf/2017-12/cp170132en.pdf (accessed on 30.06.2018). 
Parfumerie Akzente (hereinafter; Akzente), an authorized distributor in this system, sold Coty's brands in its brick and mortar shops. Akzente also carried out online distribution through its own website as well as through a third party platform, Amazon. Following the 2010 vertical block exemption reform, Coty revised the terms of its SDS so that authorized distributors would no longer be allowed to sell Coty's products by means of 'the recognizable engagement of a third party undertaking which is not an authorized retailer'3 such as the Amazon marketplace. Akzente refused to comply with these new rules. In this situation, Coty took legal action that ultimately resulted in the Superior Regional Tribunal of Frankfurt referring four questions to the Court of Justice of the European Union (hereinafter; CJEU).

Firstly, the referring court sought to clarify, whether SDSs for luxury goods that primarily aim to preserve the luxury image of such contract goods are prohibited under Article 101(1) TFEU. ${ }^{4}$ Secondly, whether imposing platform bans, that is barring members of such SDS from using third party electronic marketplaces in a manner discernible to the public (and irrespective of whether the quality standards are contravened), infringes Article 101(1) TFEU. By question three and four, the referring court wished to determine whether such marketplace bans are to be interpreted as a restriction of the retailer's customer group within the meaning of Article 4(b) of the Vertical Block Exemption Regulation (hereinafter; VBER) ${ }^{5}$, or a restriction of passive sales to end users within the meaning of Article 4(b) VBER, which are 'by object' restrictions of competition law.

The CJEU's conclusion was that (under certain conditions) SDS designed in essence to preserve the luxury image of the contract (luxury) goods, including when providing for marketplace bans that serves the same objective, is not restrictive of competition (as it falls outside of Article 101(1) TFEU altogether). By the same token, marketplace bans should not be viewed as limiting passive sales or the retailer's customer group.

\footnotetext{
3 See para. 15 of Coty Germany.

${ }^{4}$ Consolidated version of the Treaty on the Functioning of the European Union of 13 December 2007 (OJ 2012 C 326, p. 47-390).

5 Commission Regulation (EU) No 330/2010 of 20 April 2010 on the application of Article 101(3) of the Treaty on the Functioning of the European Union to categories of vertical agreements and concerted practices (OJ 2010 L 102, p. 1-7).
} 


\section{Marketplace bans are not by object restrictions}

\section{Coty's platform ban does not restrict passive sales or retailer's customer group}

Coty Germany can be divided into two parts. One concerns the use of selective distribution and the marketplace restriction in distribution of luxury products; the second one covers the nature of the marketplace restriction (whether it meets characteristics of a 'by object' restriction of competition). The automatic connotation of Coty Germany is that it makes it easier to restrict platform sales of luxury goods under SDSs because it takes out such distribution from the scope of Article 101 TFEU (the first issue mentioned above). ${ }^{6}$ It is, however, the CJEU's statement that a platform ban is not a restriction of passive sales or retailer's customer group that is more important in this judgment. This is because there are strong arguments supporting the view that this conclusion should not be limited to luxury goods and as such has broad practical significance. Therefore, contrary to the order of answers provided by the CJEU, the authors chose to consider this issue first.

Constraints on sales to end users and customers group to whom the distributor may sell are generally found to limit competition by their very nature (that is, irrespective of the effects they produce) and for this reason are referred to as 'by object' restrictions (as opposed to 'by effect' restrictions). VBER black-lists provisions restricting passive sales and limiting the ability of selective distributors to reach end customers. As a result, an agreement that contains clauses to that effect is entirely disqualified from benefiting from the block exemption. ${ }^{7}$ At the same time, it is dubious whether an agreement containing such provisions could be cleared based on an individual exemption under Article 101(3) TFEU.

The ban on third party platforms, as imposed in Coty's SDS, was perceived as possibly amounting to a passive sales restriction because in 2009 the CJEU found in Pierre Fabre ${ }^{8}$ that a clause indirectly prohibiting online sales was

${ }^{6}$ See discussion concerning this aspect in section IV below.

7 Pursuant to Article 4(b) and 4(c) VBER, the exemption laid down in Article 2 VBER does not apply to vertical agreements which have the object of restricting the territory in which, or the customers to which, a buyer party to the agreement can sell the contract goods or services, or restrict active or passive sales to end users by members of a selective distribution system operating at the retail level of trade.

8 Judgment of 13.10.2011, Case C-439/09 Pierre Fabre Dermo-Cosmétique SAS v Président de l'Autorité de la concurrence and Ministre de l'Économie, de l'Industrie et de l'Emploi, ECLI:EU:C:2011:649. 
the equivalent of a limitation of passive sales. ${ }^{9}$ In that case, the supplier of branded cosmetics and personal care products required that the products be sold in the presence of a qualified pharmacist (a condition evidently impossible to meet online). ${ }^{10}$

In the CJEU's view, a ban on sales through third party platforms, as imposed by Coty, did not go so far as to limit passive sales or to restrict the distributors' group of potential customers. The court based this conclusion on several premises, the first one being that contrary to the facts in Pierre Fabre, Coty allowed to certain extent the marketing of its products via the Internet. The distributors in Coty Germany could trade online using their own electronic shop windows dedicated to the authorized store. This option was not insignificant in view of the fact that according to the E-commerce Report ${ }^{11}$, own online shops continue to be the main e-distribution channel (a circumstance noted by CJEU earlier in the judgment). Additionally, Coty's distributors could sell using an unauthorized third party platform, provided such platform was not discernible to customers.

Secondly, the distributors could advertise online, including on third party platforms, and use search engines that could direct customers to their own online window. Both options indicated that generally Internet sales were allowed.

Lastly, it was not possible to identify the users of a third party platform as a customer group separate from all online shoppers. This presupposes that the limitation could not be effective because it would relate to a group that is not definable. In view of all above arguments, the CJEU concluded that Coty's provision did not preclude online sales in general - it excluded only a 'specific kind of Internet sale'.

9 A prohibition of online sales was also found to hinder the free movement of goods and therefore rejected in such cases as Judgment of 11.12.2003, Case C-322/01 Deutscher Apothekerverband, ECLI:EU:C:2003:664 and Judgment of 02.12.2010, Case C-108/09 Ker-Optika bt v ÀNTSZ Dél-dunántúli Regionális Intézete, ECLI:EU:C:2010:725. Both of these cases were referred to in para. 44 of Pierre Fabre to remind that 'the need to provide individual advice to the customer and to ensure his protection against the incorrect use of products' could not justify exclusion of online distribution.

10 The case was referred to the CJEU by the cour d'appel de Paris hearing appeal from the French Competition Authority's decision. This authority issued at that time a series of decisions finding that prohibiting online sales in SDS infringes competition law. Many commentators argued that the ruling lacked solid economic foundations and that the decision was driven by the policy choice to promote e-commerce. In particular, there was vivid inter-brand competition and no risk of market foreclosure (see Schmidt-Kessen, 2018, p. 4, Monti, 2013, p. 489, Colangelo and Torti, 2018, p. 10).

11 The Report from the Commission to the Council and the European Parliament, Final report on the E-commerce Sector Inquiry $\{\operatorname{SWD}(2017) 154$ final $\}$ (hereinafter; E-commerce Report), retrieved from http://ec.europa.eu/competition/antitrust/sector_inquiry_final_report_ en.pdf (accessed on 30.06.2018). 


\section{Platform bans should be assessed based on the 'by effect' approach and may benefit from exemptions}

The CJEU's conclusions on the general nature of a platform ban have two very significant consequences. Firstly, post-Coty a marketplace ban should not be considered as a 'by object' competition constraint. In view of this fact, such a restriction may potentially be harmful to competition, but it should be assessed based on the effects that it has produced or has the potential to produce. Secondly, a platform ban provided as part of a SDS is capable of benefiting from the block exemption as defined in VBER.

Should the CJEU ascertain that platforms bans restrict passive sales or customers' group, it would practically outlaw platform sale restrictions (except for those concerning luxury goods). In the current situation, the suppliers of non-luxury products wishing to rely on them have, therefore, two options.

Smaller networks may benefit from the block exemption. Pursuant to VBER, anticompetitive effects are thought not to arise as long as the supplier's and the distributors' respective market shares do not exceed $30 \%$ of the relevant market (some variations are allowed) and certain other conditions set out in VBER are met. Within these limits, all the SDSs free of restrictions characterised as 'by object' are presumed competition compliant. What is of particular importance in this context is that this presumption of legality has a very broad reach. As commentators emphasize, the benefits of VBER apply uniformly to all distribution systems, independently of the nature of the contract product, whether it is a luxury, branded or other product (Colangelo and Torti, 2018, p. 4; Ibanez Colomo, 2017b). ${ }^{12}$ Hence, in principle, the safe haven of VBER is available to a given SDS even if it entails products that are not thought to justify the introduction of selective distribution systems under the case law developed based on the Metro I and Metro II judgments. ${ }^{13}$

12 These authors point to para. 176 of the European Commission Guidelines on Vertical Restraints (OJ 2010 C 130, p. 1-46) (hereinafter; Vertical Guidelines): 'The [VBER] exempts selective distribution regardless of the nature of the product concerned and regardless of the nature of the selection criteria. However, where the characteristics of the product do not require selective distribution or do not require the applied criteria, such as for instance the requirement for distributors to have one or more brick and mortar shops or to provide specific services, such a distribution system does not generally bring about sufficient efficiency enhancing effects to counterbalance a significant reduction in intra-brand competition. Where appreciable anticompetitive effects occur, the benefit of the [VBER] is likely to be withdrawn.'

13 Judgment of 25.10.1997, Case C-26/76 Metro-SB-Großmärkte GmbH \& Co. KG v Commission, ECLI:EU:C:1977:167 (Metro I); Judgment of 22.10.1986, Case 75/84 Metro SB-Großmärkte GmbH \& Co. KG v Commission, ECLI:EU:C:1986:399 (Metro II). In broad terms, these rulings and further case law, in particular Judgment of 25.10.1983, Case 107/82 AEG-Telefunken AGv Commission, ECLI:EU:C:1983:293, recognized that certain products, due 
This is provided that such exemption has not been formally withdrawn, which can happen only if appreciable anticompetitive effects occur. Hence, VBER potentially block exempts a wide range of SDSs and diverging product categories, including those that do not require specialized distribution for reasons of their particular characteristics.

In turn, the suppliers and distributors (of non-luxury products) excluded from the benefits of the block exemption, by reason of their considerable market shares, will have the option to rely on an individual exemption in order to defend their marketplace restrictions. ${ }^{14}$ However, unlike in case of systems falling under VBER, networks where recourse to selective distribution lacks sound justification risk being considered as infringing competition. The reason behind this logic is that in cases of 'plain' products that can be distributed without specialized customer assistance and which do not require specific investments (for example, because strong brand recognition is of secondary importance for commercial success) it will be difficult to argue that a marketplace restriction brings about sufficient efficiency gains and so meets the test of Article 101(3) TFEU.

Commentators emphasize that from the economic standpoint the vertical restriction is justifiable if it is necessary to shield distributors from free riding. The risk of the latter occurs if the distribution objectively requires material downstream investments (that is, investments on the part of the distributors and not suppliers, the latter should not be shielded by vertical restraints). ${ }^{15}$ The need for such investments is not in principle limited to the distribution of luxury products or even the distribution of branded products; what counts in this context is that the distributors bear the risk of someone free riding on their efforts to boost sales. ${ }^{16}$ It is fair, however, to assume in view of the above that such investments will likely arise in the context of products that, in the meaning of established case law, are thought to necessitate recourse

to their special characteristics such as technological complexity, require specialized distribution (i.e. where customer service is ensured) and justify the imposition of restrictions that limit price competition. This is so because such purely quantitative SDSs do not limit Article 101 TFEU at all, provided some conditions (set out in footnote 37 below) are met. Whish and Bailey point out that other goods that typically justify recourse to selective distribution are products where brand image is of primary importance and newspapers due to their extremely short shelf-life (Whish and Bailey, 2015, p. 680-682). For detailed explanation of Metro doctrine see also Jones and Sufrin, 2016, p. 789-794.

14 Alternatively, they may argue that in case of their networks, a marketplace restriction does not limit competition or does so only insignificantly, e.g. because use of platforms in case of their products is negligible.

15 For more on the free-riding problem see point V.1. below.

16 See Eymard and Labate, 2018, p. 29, who raise these arguments while considering whether platform bans should be excluded from the scope of Article 101 TFEU altogether, and not just if they could be exempted based on Article 101(1) TFEU. 
to selective distribution (because of their nature) and will be rare in case of other products.

\section{Is a platform ban a hardcore restriction if applied in relation to non-luxury goods?}

Some commentators have considered whether the CJEU's conclusion that a platform ban is not a restriction of passive sales or customers' group should be limited to the distribution of luxury goods. ${ }^{17}$ This interpretation presupposes that the ban on sales through third party platforms imposed in relation to selective distribution of non-luxury goods could constitute a hardcore restriction.

The CJEU's response should not be confined to such situations. ${ }^{18}$ The primary reason supporting a broader reading of the Coty Germany is that the CJEU justified its reasoning by circumstances unrelated to the nature of the distributed good. Namely, the fact that online sales were not entirely precluded because distributors could use their own websites, or rely on the services of third party platforms (as long as their use was not discernible to the customers), use online advertisement tools, as well as the fact that it was impossible to single out platform shoppers from other customers. Additionally, when the CJEU mentions in this part of the judgment Pierre Fabre, it differentiates it from Coty Germany precisely due to the same fact (that Coty's provision did not amount to a complete restriction on online sales) and not the circumstance that, according to CJEU, the contract goods in Pierre Fabre lacked the status of luxury goods. ${ }^{19}$

Secondly, it is clear from the way in which the referring court framed its question that it sought to clarify whether general platform restrictions could benefit from the block exemption (there is no reference to the status of the goods in questions three and four). This corresponds to the fact that, as already emphasized, the benefits of VBER can be claimed irrespectively of the nature of the good. Hence it would not make sense to say that one product category can profit from VBER because of its special character (luxury products) while

17 See e.g. the discussion following Ibanez Colomo's, 2017b post.

18 Cisnal de Ugarte and Stefano, 2018, p. 29; Colangelo and Torti, 2018, p. 20; Ibanez Colomo, 2017b; Wijckmans, 2018 expressed a similar view. As Ibanez Colomo emphasizes, 'the question of whether the practice restricts active and/or passive selling over the Internet does not depend on whether the agreement is about running shoes or luxury handbags instead. This is in fact apparent from the analysis of the Court in Coty Germany' (Ibanez Colomo, 2017b).

19 The latter circumstance was noted only in the context of answers provided to the first and the second question. 
other products (non-luxury products) cannot, despite the fact that a priori the nature of the good is not a precondition for VBER to apply. ${ }^{20}$

Thirdly, in the light of the economic arguments mentioned above, it is better to concentrate on the size of downstream investment and correlated risk of free riding, rather than make a categorical classification of restrictions based exclusively on the differentiation between luxury and other products. This is notwithstanding the fact that it can be normally expected that luxury goods do require such investments. The challenge here is, however, not to deprive too easily of the benefits of VBER or an individual examination those products that require distributors' special efforts for other reasons than their luxury status or some branded products, which often will exhibit the same characteristics as luxury goods. Hence, it is more reasonable to examine the effects on competition of restrictions imposed in the context of non-luxury products before concluding on their legal nature, instead of setting them almost automatically aside as a difficult 'by object' category.

Some room to argue for a narrow reading of Coty Germany (only platform bans relating to selective distribution of luxury goods are not 'by object' restriction) provides the linguistic interpretation of this ruling. This is because in this part of the judgment the CJEU referred to the luxury status of Coty's products and mentioned the nature of the goods in the narrative of the final response. Even if the references are occasional, they are there despite the fact that the status of the goods was not mentioned in the questions asked. ${ }^{21}$ One may wonder if there was special intention to do this. A straightforward explanation may be that the CJEU simply limited the interpretation of EU law to the circumstances of the case at hand (so it corresponds to the context of a specific clause and specific distribution system that was clearly focused on creating and preserving the luxury aura of the contract product). After all, the CJEU practice of redefining preliminary questions is quite frequent. In any case, the overall logic of the response provided and other arguments discussed above, support a broad reading of the conclusions made.

In Ibanez Colomo's view, although narrow interpretation of Coty Germany is wrong, litigation on this point cannot be ruled out (Ibanez Colomo's, 2017b). This is so in particular because some national competition authorities may

20 Additionally, there would be no need to confirm that platform bans in SDS for luxury goods are not hardcore restrictions of competition, if the CJEU considered them not to infringe Article 101 TFEU in the first place. However, as the CJEU explained at the beginning, it gave it answer in the event that the referring court ascertained in view of the facts of the case at hand that it does not meet the conditions outlined in the response to question one and two.

21 See Coty Germany, para. 20(3-4), 62-65 (indirect reference by invoking 'the clause at issue') and 69. 
insist that online marketplace bans relating to non-luxury goods should be viewed as a hardcore restriction of competition. ${ }^{22}$

\section{The relevance of search engines and online advertising}

Proper understanding of Coty Germany requires considering whether the inclusion of other conditions mentioned by the CJEU that concern the use of the online environment (that is, the use of search engines, sales via own e-shop or use of online advertising, in particular on third party platforms) is relevant to the assessment of the platform ban. ${ }^{23}$

The answer to that question is in the affirmative, although it is not clear how much importance should be attached to each individual option, except for sales via own shop window. The authorization of the latter seems indispensable for a marketplace restriction to escape the qualification of an indirect prohibition of Internet sales in general.

Similarly, the possibility of using online search engines appears crucial in the modern world of e-commerce. Imposing a ban on a specific e-channel (such as marketplaces) and simultaneously excluding the general use of search engines for the benefit of other e-channels (such as own e-shops) could in fact deprive the distributors of real possibility to sell online. Combination of such restrictions could, therefore, produce results comparable to a complete ban on all Internet channels.

As regards online advertising options, it should be noted that in the context of exclusive distribution, a ban on general Internet advertising is considered a 'by object' restriction, as opposed to online advertising clearly targeting a customer group or a territory reserved for another distributor. ${ }^{24}$ However, no restrictions on sales to end users (whether final or professional end users) are allowed within selective distribution. 'Within a [SDS] the dealers should be free to sell,

22 Andreas Mundt, the President of the German Competition Authority (hereinafter; GCA), which issued a number of decisions declaring the use of platform bans in SDS as illegal (see section VII.1. below), said on 06.12.2017 that the GCA's 'decisional practice relates to brand manufacturers outside the luxury industries. Our preliminary view is that such manufacturers have not received carte blanche to impose blanket bans on selling via platforms.' The CJEU 'made great efforts to limit its judgment to genuinely prestigious products.' 'At first glance, we see only limited effects on our decisional practice' (as reported by Newman, 2017b).

23 Cisnal de Ugarte and De Stefano point out that in Coty Germany, the CJEU has assessed the legality of a specific clause in a specific set of circumstances. Therefore, a SDS that contains stricter restrictions might need to be scrutinized in light of Coty Germany, and that provisions that affect online sales should not be assessed in isolation from each other (Cisnal de Ugarte and De Stefano, 2018, para. 29, 42).

${ }^{24}$ See para. 51, 53 and 56 of the Vertical Guidelines. 
both actively and passively, to all end users, also with the help of the internet' (Vertical Guidelines, para. 56). Hence, there is a strong possibility in a SDS that the restrictions on online advertising (whether targeted at specific customers or not) will be considered a hardcore restriction. A restrictions relating specifically to advertising via third party electronic platforms could be defendable only if it is justified by the concerns for quality standards ${ }^{25}$. It is unclear, however, how the complete ban on advertising via marketplaces would impact the assessment of the ban on sales through such platforms. At the very least, it could bring a particular ban on marketplace sales closer to a disproportionate restriction in the course of the assessment under Article 101(3) TFEU.

Note that in the E-commerce Report, the Commission stated that absolute marketplace bans should not be considered a hardcore restriction. The remark was made in the context of Coty Germany. It was not, however, clarified what the Commission meant by an absolute ban, namely a ban as foreseen by Coty, which as the CJEU eventually found was not an absolute ban, or a prohibition that could go even further than the Coty's ban, for instance to exclude the possibility to advertise on third party platforms. ${ }^{26}$

\section{Risk of diverging approaches to exemptions}

Some wording in Coty Germany suggests that in individual cases, an assessment from the perspective of Article 101(3) TFEU requirements, or the availability of the block exemption provided for in VBER, may vary depending on the category of the distributed product and between member states. The primary reason for such a conclusion is that the CJEU's view on the restriction of sales through third party platforms was partly based on the results of the Commission's 2017 E-commerce Report. ${ }^{27}$ The E-commerce Report indicates that over $90 \%$ of the retailers surveyed operate their own online stores ${ }^{28}$, which continues to be the main online distribution channel. This is despite the fact that the use of marketplaces has increased over time. In such circumstances, the

25 This is because the operators of a SDS are allowed to impose quality standards relating to the use of an Internet site and to the advertisement, see para. 54 and 56 of the Vertical Guidelines.

26 See para. 41 and 42 of the E-commerce Report as well as further remarks in footnote 29 below.

27 See para. 54 of Coty Germany. The CJEU did not expressly refer to these findings in responses to questions three and four but it repeated in these responses its conclusion that Coty's ban did not completely prohibit Internet sales. The latter was formed in response to the two first questions and took account of the E-commerce Report.

28 While $31 \%$ of the respondent retailers rely on both: marketplaces and their own websites and only $4 \%$ sell uniquely on marketplaces (see para. 39 of the E-commerce Report). 
CJEU could ascertain (as the Commission did in the E-commerce Report ${ }^{29}$ ) that the platform ban in question does not amount to a de facto restriction of Internet sales (or, by the same token, to a passive sales restriction). ${ }^{30}$

However, the Commission also noted in the E-commerce Report that the intensity of use of online platforms varies between member states ${ }^{31}$, the product category and the size of the retailer (SME retailers being the group that tends to make a larger proportion of their sales via marketplaces in comparison to larger retailers). Therefore, it is possible that in some member states marketplace ban would have greater bearing on consumer choice than elsewhere. ${ }^{32}$ The effect could be additionally magnified by the fact that online platforms may be the main online distribution channel for certain product categories ${ }^{33}$ As practitioners note, those specific characteristics could remove some distribution systems from the scope of the block exemption (in particular if product markets are defined narrowly) or lead to a withdrawal of VBER's safe haven. ${ }^{34}$

29 '[T] $[$ he findings indicate that marketplace bans do not generally amount to a de facto prohibition on selling online or restrict the effective use of the Internet as a sales channel irrespective of the markets concerned.' See also comments in section III.1 (1.2). above concerning the reference to the 'absolute' market in the E-commerce Report.

30 See para. 39 of the E-commerce Report. However, the intriguing question is, first, if same disproportion exists if shares are calculated based on sales value, e.g. in reference to the Gross Merchandise Value generated. Second, if the current distribution pattern is not somewhat affected by the widespread requirement to maintain own online shop and increasing hostility of some SDS towards the distribution through third party platforms. Ezrachi notices the correlation between the use of online marketplaces and the popularity of marketplace bans, stating that the use of the latter will intensify with growth of e-commerce (Ezrachi, 2017). Interestingly, according to para. 28 of the E-commerce Report the restriction on selling on marketplaces is the second most popular vertical restriction (18\% of the respondent online retailers faced such a restriction). However, this accounts for both: absolute bans as well as restrictions on selling on marketplaces that do not fulfil certain quality criteria (see para. 40 of the E-commerce Report).

31 Germany, where $62 \%$ respondent retailers used the marketplaces, being the leader followed by the UK (43\%) and Poland (36\%); see para. 39 and 41 of the E-commerce Report.

${ }^{32}$ This is taking into account that the scope of e-commerce markets continues to be national, see Schmidt-Kessen, 2018, p. 8 and sources quoted by him. The Commission in the recent decision in Google Shopping defined the market for general search services and the market for comparison shopping services also as national in scope (see decision of the Commission of 27.06.2017 in case AT.39740 Google Search (Shopping).

33 See the statistics in para. 454 of the Staff Working Document, according to which professional sellers selling clothing and shoes on a marketplace account for, on average, $25 \%$ of all sellers on a marketplace (the most represented category followed by 'other' $(15 \%)$ and 'consumer electronics' (12\%).

${ }^{34}$ Based on Article 29 VBER. See Vinje, Paemen and Nourry, 2017 and para. 43 of the E-commerce Report. 
The above consideration reveals a risk that disadvantages stemming from a platform ban could not apply uniformly across the EU. In particular, marketplaces with a smaller reach, that is, national marketplaces, may receive less support than the ones already well established globally. In extreme situations, this could further shift the competition balance to the benefit of the latter and strengthen potential market power inequalities. ${ }^{35}$ The risk of such indirect market tipping is further increased by the specifics of two-sided markets and network effects, where market success depends on whether the platform is able to attract a certain minimum number of users (a phenomenon referred to as an initial critical mass hurdle). ${ }^{36}$

\section{The luxury of being a luxury}

\section{Legitimate nature of selective distribution and platform bans designed to preserve the luxury image of contract goods}

\subsection{Metro Conditions}

The majority of the judgment in Coty Germany concerns the analysis of whether the selective distribution systems primarily designed to preserve the luxury image of the contract goods could fall outside of the scope of Article 101 TFEU altogether, including when they provide for the platform bans. The CJEU answered this question in the affirmative and, by this statement, accorded privileged status to luxury goods in the context of distribution.

In the first place, the CJEU assessed the legality of the system in general. The CJEU confirmed that the marketing of luxury goods legitimately justifies the use of a selective distribution system and that such a system is not prohibited by Article 101(1) TFEU as long as the conditions are met for a purely qualitative SDS, as established in case law. ${ }^{37}$ The CJEU, quoting

35 See Schmidt-Kessen, 2018, p. 8.

36 Evans and Schmalensee analysed this phenomenon in detail, concluding that two-sided platforms must attract a sufficient number of users on both sides of the market to launch successfully (Evans and Schmalensee, 2010).

37 I.e. conditions established in Metro I and restated in Pierre Fabre that is: 'resellers are chosen on the basis of objective criteria of a qualitative nature, laid down uniformly for all potential resellers and not applied in a discriminatory fashion, that the characteristics of the product in question necessitate such a network in order to preserve its quality and ensure its proper use and, finally, that the criteria laid down do not go beyond what is necessary' (para. 41 of Pierre Fabre). 
the trademark case Copad $^{38}$, recognized that an aura of luxury bestowed on the product by an alluring and prestigious image is an essential quality that distinguishes such goods from others, and for this reason it is equally important as the good's material characteristics. Therefore, an aura of luxury, and the means of creating, sustaining and reinforcing it, such as special distribution requirements imposed in the SDS, are worthy of protection. The CJEU clarified also that the Pierre Fabre judgment ${ }^{39}$ should be read against specific circumstances of that case. Pierre Fabre, the CJEU emphasized, had not established a statement of principle whereby the preservation of a luxury image could no longer justify use of selective distribution (in respect of any goods, including luxury). ${ }^{40}$

In the second place, the CJEU assessed the individual provision in SDS, namely a platform ban. Also here the CJEU confirmed that a platform ban may constitute a legitimate requirement for the selective distribution of luxury goods. The CJEU, after recognizing the legitimate nature of the clause ${ }^{41}$, considered in detail if the ban was proportionate, that is, whether it sought to preserve an essential characteristic of the contract goods (luxury image) in (i) an appropriate and (ii) least restrictive manner possible (meaning that it did not go beyond what was necessary to attain that goal).

In the court's view, the restriction was appropriate, firstly because it ensured that the goods in question are associated solely with the authorized distributors (and creating such an association is an inherent characteristic of selective distribution). Secondly, the clause allowed the supplier to effectively monitor whether the distribution requirements are adhered to. In this respect, the CJEU noted that absent a contractual relationship with a third party platform, the supplier would be unable to enforce compliance and so prevent possible deterioration of the image of the product caused by inappropriate

38 Judgment of 23.04.2009, Case C-59/08 Copad SA v Christian Dior couture SA, Vincent Gladel and Société industrielle lingerie (SIL), ECLI:EU:C:2009:260.

39 Para. 46 of this judgment to be exact, according to which: '[t]he aim of maintaining a prestigious image is not a legitimate aim for restricting competition and cannot therefore justify a finding that a contractual clause pursuing such an aim does not fall within Article 101(1) TFEU'.

40 See para. 34-35 of Coty Germany. The CJEU concluded that the assertion in para. 46 of Pierre Fabre related 'solely to the goods at issue in the case that gave rise to that judgment and to the contractual clause in question in that case.' (para. 34 of Coty Germany). The meaning of the Pierre Fabre judgment was therefore confined to clarifying that the need to preserve the prestigious image of cosmetics and body hygiene goods cannot legitimately justify a complete exclusion of such product from online distribution. The statement clearly defines the limits of the Pierre Fabre ruling.

41 The individual requirement is of legitimate nature if, according to the general principle, it is applied in a non-discriminatory manner to all distributors, it pursues a legitimate objective, such as preservation of the luxury image of the contract goods and is objective and qualitative in nature. 
presentation. Thirdly, online platforms are channels primarily designated for the distribution of goods of all kinds, therefore the clause sought to ensure an appropriate (selective enough) sales environment. ${ }^{42}$ The provision was also not overly restrictive as the ban did not preclude the use of platforms in a non-discernible manner, or sales in the distributors' own e-shops, or the use of search engines and online advertising.

\subsection{The rationale behind the protection of the image of luxury goods}

The first two arguments relating to the appropriate nature of the provision resemble the logic of the Copad judgment, which was a trademark (hereinafter; TM) case. This justification heavily relies on the rationale behind TM protection, in particular the indication of origin and protection of values associated with the origin such as brand reputation. For these reasons, it is to some extent inconsistent (not that the authors disagree with the premises of TM protection). It is simply not true that a supplier would have no means of enforcing compliance with the distribution requirements vis- $a$-vis third parties (here, an online platform). Trademark licences and the Copad judgment itself provide such grounds (according to that judgment, a supplier may prevent a third party reseller from trading in goods that the reseller acquired $^{43}$ from a selective distributor in contravention of SDS' conditions). Additionally, private law offers a wide range of measures that can make

${ }^{42}$ It is interesting to note in this context that some Internet marketplaces create specialised zones dedicated to the sale of branded goods. This market development was noted by the French Competition Authority (see discussion in section VII.4 below). Would the exclusion of such services also stand the CJEU's scrutiny? Would evidence confirming the customer's high-standard experience be sufficient to consider such ban disproportionate? The answer to this question depends on the courts' appetite for sealing the distribution of exclusive goods from the online environment. Ezrachi argues that the proportionality of the marketplace bans raises doubts when legitimate qualitative concerns can be addressed effectively by modern marketplaces. He says that in those circumstances, such a ban would be just a tool limiting price competition (Ezrachi, 2017). Petropoulos expressed a similar view (Petropoulos, 2018, para. 79-80). In turn, Bagdziński questions the added-value of platform restrictions aiming exclusively at protecting the product presentation, while the e-shops of authorized distributors do not offer any enhancement in the quality of the service (Bagdziński, 2018, p. 126).

${ }^{43}$ In this case ownership of goods was effectively transferred from the selective distributor to the reseller, whereas this would not normally be the case when the distributor sells his contract goods via an e-platform. Therefore, under the Coty Germany facts, the supplier's case against a third party platform selling goods in contravention of the SDS's requirements would be even stronger (as the restriction would relate to goods owned by an authorized distributor, a party to the SDS). 
certain contractual provisions effective against third parties. ${ }^{44}$ Lastly, Coty's SDS allowed distribution via a third party platform as long as its use was not recognizable to the customers. Following the CJEU's approach, in such case the enforcement of SDS' requirements would be equally difficult.

Perhaps, one of the rationales behind Coty's restrictions, which was not discussed in the judgment, is related to the scale of sales. ${ }^{45}$ The scale of sales via third party platforms on one hand makes it difficult for the supplier to survey compliance with the distribution requirements. On the other, it may dilute the aura of luxury, because as Roumeliotis notes, the more available a brand is, the less luxurious it becomes, therefore commoditizing luxury brands on the middle market risks diluting their luxury status (Roumeliotis, 2015).

Moreover, marketplaces are about transparency that creates downwards pressure on price. It does not go well together with the fact that the distribution of luxury goods may be characterised by the Veblen effect, an economic phenomenon named after the American economist Thorstein Veblen (Gulcz, 2002, p. 34). ${ }^{46}$ The effect describes a reversed price - demand relation where, in contrast to typical market rules, high prices of luxury goods generate additional demand because such goods are a high status symbol and are used to convey the appearance of success. To put it bluntly, for some customer categories it would be less interesting to possess a Gucci hand bag if it would cost less and be available to everybody.

A conclusion that stems from the above is that in the case of luxury goods, creating scarcity may generate added-value, even if it helps maintaining high prices. Recognizing this kind of interrelation is challenging in the world of competition. This argumentation also comes dangerously close to quantitative restrictions that, as a rule, are not considered to fall outside of Article 101(1) TFEU. The above circumstances may explain why the CJEU retreated in Coty Germany to the familiar language of TM protection. ${ }^{47}$

${ }^{44}$ Ezrachi notes that even if the manufacturer has no direct control over the marketplace (be it a traditional shopping mall or an electronic platform), it may hold the distributor accountable for a failure to comply with legitimate requirements (Ezrachi, 2017).

45 The other one would be the value of investments made in creating the product's renown and protection of different techniques used to achieve it. Those have been addressed indirectly by reference to the Copad language, it seems.

46 For an illustrative explanation of the paradox see: https://www.investopedia.com/terms/v/ veblen-good.asp (30.06.2018).

47 Schmidt-Kessen considered Coty Germany a welcome reconciliation between competition and trademark law rationales. He argued that after Pierre Fabre, competition law started to run dangerously counter rules and main values behind TM laws. The judgment eased that tension by recognizing that 'brand image protection, at least for luxury goods, can constitute a legitimate aim for an SDS under EU competition law' (Schmidt-Kessen, 2018, p. 8). 


\section{Practical implications}

\subsection{Protection of the image of a luxury good is a legitimate objective}

The CJEU findings, provided in responses to the fist and the second questions, confirmed that the protection of a luxury image is a legitimate objective that may justify recourse to SDS. Bernard argues that it also put on equal footing authorized distributors and the electronic marketplaces, in the sense that distribution through marketplaces is possible only if the later belongs to the authorized network (Bernard, 2018, p. 35).

\subsection{Simplified verification track for luxury goods}

Most of all, however, the ruling took the selective distribution of luxury goods, including those that provide for limited platform bans, out of the scope of Article 101(1) TFEU. Such provisions, like other qualitative requirements typically imposed in SDS, do not limit competition. ${ }^{48}$ The practical meaning of this part of the judgment is that it accorded a privileged status to the distribution of luxury goods. Namely, the suppliers of such goods profit from a simplified verification track: when creating the distribution system they do not have to consider whether the system is capable of disproportionately affecting competition and to look for additional justifications that would outweigh its possible detrimental effects. Their systems are simply presumed legitimate as long as the conditions set out in Coty Germany are met.

More importantly, the benefit applies irrespective of how big the supplier's and the distributors' market shares are. This is a clear advantage when compared to distribution systems that are subject to the standard Article 101 TFEU test, especially when considering that some of them are also removed from VBER because their market shares exceed the $30 \%$ threshold. Additionally, it can be expected that online sales restrictions will continue to be carefully scrutinized due to their potentially considerable impact on the markets. The latter circumstance will increase challenges that SDSs for non-luxury goods will be faced with, for example, how to define their relevant markets and so

48 Wijckmans emphases that the qualitative restrictions in SDSs are outside the realm of Article 101(1) TFEU because they are objectively justified. Additionally, he points out that Coty Germany confirms that 'objective justification theory is essentially linked to the nature of the goods or services at hand', whereas the nature of the product is irrelevant for the application of the block exemption benefit provided for in VBER. The objective justification theory also differs from the ancillary restraints concept. The latter are not restrictive of competition only and as long as the objectives of the main agreement (to which they are ancillary) do not restrict competition (Wijckmans, 2018, p. 2). 
assess market shares. Post-Coty, networks designed for luxury goods are free of these concerns.

\subsection{Recourse to exemptions (mixed systems, goods with unclear status)}

The above advantages are, however, available provided that all of the SDS' requirements are purely of a qualitative nature and the contract goods are luxury. It will be still necessary to meet the standard Article 101(3) or VBER tests in order to escape competition law risks where the luxury nature of a contract good is contestable or difficult to prove (as may be often the case in view of the uncertainties around the definition of 'luxury', as discussed in the next section).

The same holds true in case of mixed systems (applying qualitative and quantitative criteria) or failing to meet Metro-based requirements set out in Coty Germany. The reason behind this statement is that solely those selective distribution systems that implement exclusively qualitative requirements fall outside the realm of Article 101(1) TFEU. In practice, however, qualitative requirements are often combined with quantitative ones, and the nature of some of them is not obvious. For example, such requirements as: minimum sale or minimum percentage of turnover, purchase requirements, sales targets, minimum stocks or requirements to stock the complete range of products, as well as promotion requirements may all qualify as indirect quantitative restrictions. ${ }^{49}$

\subsection{The brands at the beginning of their market circle and 'commonized' brands}

Now the practical question that remains is how to apply this system when a given brand is at the beginning of its market life. We speak of situations when the producer decides from the outset that he intends to create a luxury brand. He is, however, at the beginning of the process and has no empirical evidence available to support claims of luxury (because there is no aura of luxury as yet). The opponents of the liberal approach would reason that in this kind of situation any brand would argue for luxury status so it can implement platform bans. These concerns are not warranted.

Firstly, for practical reasons not every brand will aspire to such prestige. Secondly, even in the early phases of market life it should be possible for the producer to provide consistent evidence that supports the product concept such as, for example: designs, corresponding product and service standards, adequately high marketing budgets and strategies, targeted clients, etc. In

49 See para. 175 and 179 of the Vertical Guidelines and Whish and Bailey, 2015, p. 634. 
sum, it should be up to the individual producer to decide its own branding and marketing strategy, but he should be prepared to produce consistent evidence to support his claims. If a producer commits to create a product that stands out, that he wants to be exclusive, he should have the right to decide in what conditions it is to be sold. ${ }^{50}$

Thirdly, and most importantly for practitioners, it should not be difficult to advise such a client because of the possibility of reaching to VBER. Usually such a producer would not have high market shares and so would be capable of benefiting from the block exemption. There would be enough time to create an aura of luxury and corresponding evidence before the VBER's market share limits are exceeded, and the need to resort to a defence based on the 'luxury' status (that is, the Coty Germany exception) materializes.

The situation would, however, be more difficult in cases of established luxury brands with possibly high market shares that have been subsequently commoditized and so lost their prestigious status. We refer here to a risk mentioned by Roumeliotis, as discussed in point III.1. above. In this situation, the recourse to Article 101(3) TFEU could be a viable alternative, as normally the change in the brand's status will not remove the free riding risks materializing at the distributors' level.

\section{How to define 'luxury'?}

Notwithstanding the advantages of the system described, the challenge about Coty Germany is that the CJEU has neither defined the term 'luxury product', nor provided straightforward indications on how to delineate this product category. A sort of guideline regarding what exactly constitutes a luxury product can be pieced together from the previous case law and different opinions of Advocates General. What seems to be a recurring wording is 'that the quality of luxury goods is not simply the result of their material characteristics, but also of the allure and prestigious image which bestows on them an aura of luxury'. ${ }^{51}$ This unquestionably does not provide a clear-cut

50 Therefore, the CJEU's suggestion that cosmetics and body hygiene products such as Pierre Fabre's ones could not aspire to be luxury goods will not always prove correct.

51 CJEU Press Release No 132/17 of 06.12.2017, retrieved from: https://curia.europa. $\mathrm{eu} / \mathrm{jcms} /$ upload/docs/application/pdf/2017-12/cp170132en.pdf (accessed on 30.06.2018). The definition of luxury goods was also discussed in para. 39, 45 of judgement of 04.11.1997, Case C-337/95 Parfums Christian Dior v Evora, ECLI:EU:C:1997:517; in para. 24-26 of Copad and in para. 114-115 of Judgement of 12.12.1996, Case T-19/92 Groupement d'achat Edouard Leclerc v Commission of the European Communities, ECLI:EU:T:1996:190. 
set of criteria allowing one product category to be neatly differentiated from another.

A number of factors and corresponding questions may help to define the good's status. For example, is the proportion of the value derived from the aura of luxury to the material worth or quality of the product relevant ? $^{52}$ Whose perspective would be decisive in that regard, would consumer surveys constitute sufficient evidence of the status? Does the consumers' main purchasing incentive have to be the good's luxury status? Should local conditions and preferences be taken into account, including disparities across the member states? ${ }^{53}$ Would the proportion between the product price and the production cost be of any relevance? What bearing should the advertising costs (typically high in cases of luxury goods as it is a renown-creating factor that impacts consumer preferences) have? What is the relevance of the distinction between 'luxury' products and 'premium' ones and how to distinguish them?

On the latter point, Heine points out that a genuinely 'luxury' product has certain intrinsic, identifiable characteristics: extremely high price, aura of exclusivity, its custom make of 'royal' materials and the limited target group of clients ('select few'), (Heine, 2012). Baicoianu explains that a premium product on the other hand, although still priced higher than the average good, is accessible to a wider array of consumers, both price-wise and distributionwise (Baicoianu, 2013).

Roumeliotis differentiates the two categories in the following way: 'A luxury brand is very expensive, exclusive and very rare - not meant for everyone [...]. Authentic luxury brands compete on the basis of their ability to invoke exclusivity, prestige and hedonism to their appropriate market segments not the masses. [...]. If luxury brands are related to scarcity, quality and storytelling, then premium goods, on the other hand, are expensive variants of commodities in general: i.e. pay more, get more. These brands are less ostentatious, more rational, accessible, modern, best in class, sleek design, and manufactured with precision.' (Roumeliotis, 2015).

These concepts refer to a number of helpful but uneasy to measure criterions, which only illustrate the challenges that business will have in applying Coty Germany. The above and many other questions will be tackled by national courts and competition authorities on a case by case basis with the risk of differing results across the member states.

52 A. Mundt in his capacity of the President of the GCA suggested while commenting Coty Germany that the meaning of the term is confined to products 'whose whole point is to convey an aura of luxury' (See Cisnal de Ugarte and Stefano, 2018, footnote 126; Newman, 2017b and footnote 22 above).

53 E.g. a specific product might be considered as a luxury in one member state and just as a branded good in another, due to different shopping patterns and affordability levels. 


\section{Are selective distribution and platform bans designed to preserve the image of non-luxury products outside of Article 101 TFEU?}

The differentiation between luxury goods and premium ones brings up, however, a more fundamental question namely whether the CJEU's findings on the legality of selective distribution and platform bans should extend beyond the category of luxury products (similarly to the view that platform bans are not a hardcore restriction).

The way in which the referring court framed its first and second question and the language used in responses to them leave no doubt that the CJEU's conclusions are restricted to luxury goods. Many commentators argue, however, for a broader application. Ibáñez Colomo points out that trademark law protects all producers, including those supplying non-luxury goods, and there is no reason why EU competition law should be different. Conveying a particular image, he says, may be also important for the latter companies (Ibáñez Colomo, 2017b).

Economists reason that it is the size of the investments and the parties' market shares, rather than the nature of the good, that matter while determining the impact of vertical restraints on competition. Moreover, branded and premium products often will exhibit the characteristics that the CJEU has recognized in Coty Germany as worthy of protection (Eymard and Labate, 2018; Harvey, 2018). According to Harvey's reading of Coty Germany, the CJEU singled out 'luxury' goods by reference to two circumstances: (i) the way the goods are displayed impacts the strength of the product's allure, image and reputation and (ii) the latter affects in turn the good's actual quality. $\mathrm{He}$ argues that the same interrelation arises in the case of a wide range of branded goods (and across the entire brand, instead of in relation to an individual product category within the brand), (Harvey, 2018). His conclusion is based on simplified economic models measuring customers' purchasing behaviour and the relevance of investments in advertising and marketing.

Nonetheless, the current system appears reasonably balanced. The protection of a luxury image is simplified, in that it benefits from a presumption of legality (as SDS and platform bans aimed at protecting it are altogether outside the realm of Article 101 TFEU). Broad protection of the image in the case of other (non-luxury) brands is also ensured by VBER, but it requires more thinking after a certain level of market power is exceeded, that is, the manufacturer's or the distributors' market shares grow above 30\% (Article 101(3) TFEU analysis). This is reasonable given the importance of market power in the assessment of vertical restraints in general and the significance of platform bans in particular. 
In this system the term 'luxury product' should be construed with care for at least two reasons: Firstly, even if some products fail to qualify for the status, it will be still possible for them to profit from exemptions. At the same time, application of general rules will make it easier to monitor the true effects of platform bans that such SDS may now entail, and to prevent an overly broad application of this restriction. Secondly, the arguments based on added-value generated by scarcity and the aura of luxury interrelation ${ }^{54}$ do not apply to all branded products. Without it, the product and the value it represents would not exist at all. This justifies a privileged position of truly luxury products without prejudging, however, admissibility of similar restrictions for other products.

\section{Pros and Cons of platform bans}

It is interesting to have a brief look at the main arguments that the opponents and the advocates of platform bans advance in support of their positions. A better understanding of the interest at play helps to identify potential efficiencies and reductions in competition, which will have to be weighed each time a specific platform ban does not qualify either for the Coty Germany exception or the block exemption benefit.

\section{Price transparency v. free-riding}

The opponents of online marketplace bans claim that they 'deprive European sellers of more opportunities and consumers of more choice and price competition.' (Greenfield, 2017b). One of the key arguments in favour of marketplaces is that by reducing search costs they make it easier to compare prices and offers. Marketplaces therefore increase price transparency and diminish information asymmetry, hence they intensify intra- and inter-brand competition to the advantage of customers. It is argued that in such a situation suppliers are not able to take advantage of ill-informed consumers (Ezrachi, 2017). Instead, suppliers have to win the customer by offering additional benefits or increasing the quality of their service. The net result may be downward pressure on prices and an increase in competition by quality, for instance by offering additional services such as free or faster delivery

${ }^{54}$ See section IV.1 above. 
options, additional advice, etc. 55 The benefit could be lost when e-commerce is channelized into independent websites and offline shops.

On the other side of the arena, stakeholders argue the opposite. Colangelo and Torti, state in a broader context of Internet restrictions that even if online distribution is a particularly powerful means of driving price competition, it does not mean that restrictions relating to it are always more problematic than those relating to less price-oriented distribution channels (Colangelo and Torti, 2018, p. 10). The authors emphasise (after Buccirossi, 2015) that in some cases selling online may have a detrimental impact on competition focused on quality and provision of ancillary services (Buccirossi, 2015, p. 770; Colangelo and Torti, 2018, p. 10). Buccirossi points out that 'selective distribution is frequently motivated by the need to prevent distributors from focusing only on price competition' (Buccirossi, 2015, p. 752). That objective has been recognised in the Metro I and Metro II rulings, where it was held that price competition can give way to competition on quality. The courts endorsed therein the price limitation, because it was essential to safeguard the existence of specialized distribution, including by ensuring reasonable profit margins required to cover the cost of investing in a high-quality service.

These concerns are reflected in the E-commerce Report. The Commission notes that increased pressure on price (resulting from the move to online distribution in general) may adversely affect competition on quality, innovation and brand by way of the free-riding effect. ${ }^{56}$ Allowing unrestricted show-rooming (a situation where a customer views the goods in a traditional shop but purchases them online) undermines the retailers' incentive to invest in a high quality service. ${ }^{57}$ The ultimate result may be a reduction in inter-brand competition as the quality, innovation and brand image are the main driving force behind it. The latter are also the major concerns for maintaining the visibility of businesses in the mid and long term. ${ }^{58}$

55 As the Commission Staff Working Document reveals, retailers generally believe that the limitation on the use of platforms will remove downwards pressure on retail prices and eventually stabilise them to the advantage of traditional trade and the manufactures' own online distribution (see para. 456 of the Commission Staff Working Document Accompanying the document Report from the Commission to the Council and the European Parliament Final report on the E-commerce Sector Inquiry $\{\mathrm{COM}(2017) 229$ final $\}$, (hereinafter; Staff Working Document), retrieved from http://ec.europa.eu/competition/antitrust/sector_inquiry_swd_en.pdf (accessed on 30.06.2018).

56 Such effect occurs when consumers buy from retailers who do not invest in the quality of service and instead pass on the resulting cost-savings to consumers by charging lower prices (Buccirossi, 2015, p. 751).

57 Such hold-up problems are best solved by restraints limiting intra-brand competition that, at the end of the day, are in the interests of manufacturers and customers. Otherwise, a low mark-up may lead to under-investment in service quality (Colangelo and Torti, 2018, p. 13).

58 See para. 12 of the E-commerce Report. 
One should not overlook in the context of the above considerations that, on the one hand, increased price transparency is a characteristic of e-commerce in general and not only of marketplaces. Therefore not all the above advantages are lost in cases of marketplace bans in SDS that do not preclude other means of online sales, as was the case in Coty Germany. On the other hand, the retailers may react to intensified price competition by adopting price-obfuscation tactics, such as making the price difficult to interpret, for example by creating multiple versions of products. ${ }^{59}$ Additionally, some sources indicate that online prices are not necessarily lower than the offline ones (Duch-Brown and Martens, 2015, p. 3, 22-23).

\section{Aggregation of consumer demand}

It is also claimed that virtual marketplaces help to aggregate consumer demand. The effect is achieved by providing the customers with a high quality, trust-generating shopping experience, convenient infrastructure and by use of different advertising and marketing tools, among other things. The benefits stretch over both ends of this two-sided market. Customers are able to find in one place a wide variety of products that comprise not only the goods they are specifically looking for, but also those that accidentally attract their interest and hence create an additional demand. Sellers profit from traffic generated by other merchants to market their goods and make them visible to a greater number of potential buyers and to expand their offer.

The characteristic of marketplaces may, however, clash with the distribution and brand image strategies of manufacturers. ${ }^{60} \mathrm{It}$ is worth noting in this context the theory of silent thinking considered by Colangelo and Torti as developed by Helfrich and Herweg, 2017 (Colangelo and Torti. 2018, p.14). According to this theory, consumers are more willing to pay for (expensive) branded goods in a high price environment, because in such environment they are focused rather on quality than on price. It implies that manufacturers have an interest to restrict online (low price) sales, which can be a questionable strategy from the perspective of customers' interest.

\section{Access to the market and cross border trade}

Marketplaces are considered to generate economies of scale that improve access to markets. The platforms offer expertise (technological and often

\footnotetext{
59 See in more details Buccirossi, 2015, p. 755.

${ }^{60}$ See para. 14 of the E-commerce Report.
} 
commercial) otherwise unavailable, in particular to smaller market players. In simple words, those users may rely on the marketplace's ready-made infrastructure, such as the interface design or payment systems (Colangelo and Torti, 2018, p. 8). As Greenfield (quoting J. Kucharczyk, President of the Computer and Communications Industry Association (hereinafter; CCIA)) emphasize, this generates new opportunities. For instance, the marketplaces' offer of quality apps, enables the sellers to use mobile devices as a new marketing channel (Greenfield, 2017a). Moreover, it is claimed that online marketplaces help to increase cross-border trade. ${ }^{61}$

Overall, it is said that marketplaces make it easier to start an online business as they do not require high investments upfront. Online businesses in general have lower stock and logistics costs (Duch-Brown and Martens, 2015 , p. 3). However, the use of the marketplace further helps to mitigate some of the costs and risks associated with e-commerce. The leitmotiv of the German Competition Authority is that thanks to marketplaces small and medium retailers can compete on an equal footing with larger retailers and manufacturers. The latter increasingly compete with own retailers online. ${ }^{62}$ As argued in the Adidas and ASICS decisions, ${ }^{63}$ on one hand customers favour marketplaces because of proven customer experience, the system of endorsements and trusted payment methods. On the other hand, offers from smaller retailers' own online shops are invisible if they are not powered by marketplaces where customers normally initiate their search. Marketplaces make it possible for smaller retailers to compete for higher ranks in general search engines results, otherwise dominated by large retailers and manufacturers.

The sceptics of marketplaces advance in turn that marketplaces increase the risks related to reputation and brand-image, including sale of counterfeit products. Additionally, this distribution channel does not ensure sufficient preand post-sales service, which in the long run can be detrimental to specialized distribution.

61 'Online marketplaces make the digital single market a reality today by enabling sellers to reach consumers across the EU.' (Greenfield, 2017a). The Staff Working Document indicates that about a third of the retailers that responded to the questionnaire consider use of marketplaces to be one possible way of expanding their sales abroad. In general, the results suggest that marketplaces facilitate cross-border sales and that retailers that sell (also) via marketplaces are more likely to sell abroad (see para. 360 and 446 of the Staff Working Document).

62 See comments from the President of GCA, Andreas Mundt as reported in Altrogge, 2017; Hunter, 2017.

63 See section VII.1 below. 


\section{Price comparison tools}

\section{PCT Pros and Cons}

The Commission noted in its E-commerce Report the increased use of vertical restraints that is linked to the growth of e-commerce. The restriction on the use of price comparison tools is the fifth most popular one ${ }^{64}$, and possibly next in line to be assessed by the courts. PCT restraints may take different forms. The Commission notes limitation: (i) to use, sell or promote on any PCT (total ban or requirement to receive prior approval from the supplier ${ }^{65}$ ) or (ii) on PCT that is specifically targeted at customers in other territories; (iii) to actively provide data feeds (price and product information) to PCTs; (iv) to use PCTs that present individual products and prices instead of focusing on the whole range of a given manufacturer's products; (v) to use the brand name, information, images provided by the manufacturer or (vi) making use of PCT dependent on certain quality criteria. ${ }^{66}$

The concerns voiced in relation to PCTs and marketplaces are often similar. Manufacturers fear that PCT focus on price competition and may make customers increasingly price sensitive, resulting in downward pressure on prices and reduced margins. This undermines the retailers' incentives to invest in service quality ${ }^{67}$ and limits the sellers' ability to differentiate from others in terms of scope and quality of service. For these reasons, the PCT may be detrimental to brand image and consumer choice in the long run, in particular by reducing the number of specialized retailers (both traditional and online). The latter, having a higher cost structure, may have difficulties in matching the prices if the retailers are undercutting 'each other's prices to feature prominently on price comparison tools'. ${ }^{68}$ It is also noted that PCT may give an unfair boost to second hand and counterfeit products, which rank higher in the search results.

${ }^{64}$ See para. 15 of the E-commerce Report. The proportion of retailers that have agreements containing a restriction on the use of PCTs is the highest in Germany (14\%) followed by the Netherlands and Austria (13\%), while it is quite low in Poland (7\%) and France (6\%). This corresponds with the proportion of retailers actually using a PCT, which in Germany is only $34 \%$ (the third lowest) and $48 \%$ in the Netherlands. The highest proportion is $61 \%$ (France) and $55 \%$ in Poland (third highest). Austria comes as a surprise, as it is the second (58\%), despite the quite high proportion of retailers having such restrictions (see para. 521 and 526 of the Staff Working Document).

65 The Commission thinks that a requirement to receive prior approval equals an outright ban.

66 See para. 528 and next of the Staff Working Document.

67 E.g. such aspects as delivery/return options, luxurious image, quality, features and style (para. 535 of the Staff Working Document).

${ }^{68}$ See para. 537 of the Staff Working Report. 
Some manufacturers note, however, the positive impact of PCTs, because customers rely on them when making purchasing decisions and PCTs provide helpful product and seller reviews. They also make it easier to find authorized dealers and enhance brand visibility online. ${ }^{69}$

The restriction on PCT was discussed in the German ASICS case, ${ }^{70}$ as ASICS prohibited its authorized distributors from linking their own websites to price comparison engines. The GCA considered that it was seriously undermining the ability of small and medium distributors to compete in the online world because PCTs have been important for making their offers visible. Therefore, the restriction was considered to be a 'by object limitation' of passive sales, unrelated in any way to quality requirements and 'not justified as a measure to protect brand image. ${ }^{71}$

\section{The Commission's stance concerning PCTs ban}

According to the Commission, an absolute ban on price comparison tools may amount to a 'by object' restriction on passive sales and the retailer's customer group under Article 4(b) and (c) VBER. However, milder limitations are covered by VBER. For example, restrictions based on objective qualitative criteria in SDSs or restricting the use of tools specifically targeted at a territory or customer group reserved within exclusive distribution (the two may not be used simultaneously, though).

The Commission, noting that PCTs further facilitate price competition on the Internet, based its view primarily on two considerations. Firstly, the tools increase the retailers' visibility and allow the generation of traffic to the retailers' own websites. Thanks to PCTs, customers can at a very low cost find and compare the offers of different sellers. Limiting these options would make it more difficult for the retailers to reach out to customers outside their physical trading area, including attracting customers to the authorized distributors' own online stores. ${ }^{72}$ In general, an absolute PCT ban risks undermining the benefits of the Internet that allows increasing visibility of authorized dealers.

69 Ibid., para. 534.

70 The decision is discussed in more detail in section VII (1.2.) below.

71 See ASICS Summary Decision, p. 8 (for detailed references see footnote 93 below).

72 This has to be read in the context of the growing direct presence of the manufacturers, a phenomenon noted in the ASICS decision discussed below and by Ezrachi (Ezrachi, 2016). The retailers, including authorized ones, increasingly have to compete not only with other brands but also with own suppliers, who benefit from better visibility and price flexibility, among other things. 
Secondly, price comparison tools are not a distinct online sales channel, and it is not there that competition takes place. 'The actual sale generally does not take place on the website of the price comparison tool, but on the website of the retailer to which potential customers are directed $[. .$.$] at which point$ the connection to the price comparison tool ends. ${ }^{73}$ In this respect, PCTs are different from marketplaces and do not affect authorized distribution systems (Colangelo and Torti, 2018, p. 20). Presumably, this fact is to diminish the risks stemming from increased focus of PCTs on price competition (not quality) and fear that it limits the sellers' ability to differentiate from competing offers. The Commission discarded the latter concerns about brand image by pointing out that more than $90 \%$ of PCTs improved the quality and image of the service. The upgrading included optimization of search relevance and interfaces as well as enhanced product presentation, fraud monitoring and customer protection. ${ }^{74}$

\section{Practical implications}

The Commission seemed to treat PCTs as an advertising tool rather than a distribution mode of its own. The arguments presented in support of PCTs as compared to marketplaces are somewhat unconvincing, as the main feature of marketplaces is also enhanced price transparency and offer visibility (as argued by the GCA in the Adidas and ASICS cases).

The practical consequences of this approach are that first, absolute bans on PCTs will not benefit from VBER and will be difficult to defend under Article 101(3) TFEU. Secondly, manufacturers have to carefully draft any quality requirements in order not to qualify for an absolute PCT ban. Thirdly, any quantity-based restrictions may be prone to disqualification. Lastly, and more generally, it confirms that any limitations that come close to a restriction on promotion and advertising in the online environment risk being perceived as restraints on passive sales unless explicable in light of the Vertical Guidelines (as already pointed out in section III.4 above).

\section{National examples}

There are several decisions from courts and authorities of Germany, the Netherlands and France concerning marketplace bans that either predated or

73 See para. 516 of the Staff Working Document.

${ }^{74}$ See para. 540 of the Staff Working Document. 
followed Coty Germany. German jurisdiction is not only the one from which the Coty Germany case originated, but also the one that has delivered quite a substantial number of decisions relating to marketplace and PCTs bans. This is not surprising in view of the fact that Germany has the highest proportion of retailers using marketplaces. ${ }^{75}$ This case law is illustrative in the context of the previously mentioned risk that post-Coty disparities may continue to appear at national level in respect of marketplace bans. It also highlights the bearing that different facts may have on the assessment of platform bans, for instance the importance of the marketplace status (whether it was admitted to the SDS or not) or if concerns for reputation are uniformly applied online and offline (ban on sales via marketplaces v. authorisation of sales in offline discount shops).

\section{German Competition Authority cases}

\subsection{Adidas Decision (sportswear)}

The GCA initiated proceedings against Adidas AG (hereinafter; Adidas) after having received complaints regarding Adidas's changes to its SDS introduced in 2013. According to the amendment 'consumers could not call up the [distributors'] site via or through a third-party platform if the logo of the third party is visible. ${ }^{.76}$ In effect, this provision banned sales via third party platforms; only the use of marketplaces such as Zalando (closed marketplaces ${ }^{77}$ ) was allowed.

The GCA, disregarding the Logo Clause from the Vertical Guidelines, para. $54^{78}$, held in Adidas Decision ${ }^{79}$ that a per se ban on sales via online marketplaces constitutes a restriction of competition within the meaning of Article 101(1) TFEU. The authority found that such a blanket ban was not based on qualitative criteria, which would serve the objective purpose

75 See para. 452 of the Staff Working Document.

76 Adidas Summary Decision, p. 1.

${ }^{77}$ In these marketplaces, the retailers' offers are integrated with the platform-operator's shop.

78 Under VBER, a supplier operating an SDS is allowed to impose certain conditions for the online sale of its products by authorized distributors. A 'logo clause' that concerns marketplaces, is one of the examples given to illustrate this point. Pursuant to it, 'the supplier may require that customers do not visit the distributor's website through a site carrying the name or logo of the third party platform.'

79 Decision of 27.06.2014, Case B3-137/12 (hereinafter; Adidas Decision). The summary decision is available here: https://www.bundeskartellamt.de/SharedDocs/Entscheidung/EN/ Fallberichte/Kartellverbot/2014/B3-137-12.pdf?__blob=publicationFile\&v=2 (30.06.2018) (hereinafter; Adidas Summary Decision). 
of protecting the brand image. The authority's primary concern was that Adidas ultimately restricted the number of consumers that its distributors could reach via the Internet, in particular small and medium distributors. As the authority emphasized, the latter cannot afford expensive nationwide advertising and are consequently dependent on being discovered by consumers by means of marketplaces. ${ }^{80}$ Listing and advertising on general search engines was not a viable alternative as they are usually dominated by large retailers or manufacturers. Only listings from marketplaces could compete with the latter for higher ranks.

Furthermore, the GCA considered that Adidas could not justify the ban by reasoning that only experience with closed marketplaces was adequate, because customers' needs for professional advice vary depending on the product. Marketplaces (particularly bigger ones) are favoured due to the convenience and reliability of other customer reviews; they are also considered 'safer' and more trusted. The restriction was, therefore, ignorant of consumer preferences. Adidas could deprive customers of their favourite distribution channel only if the restriction would effectively remedy free riding problems, but that was not the case here. In this respect, the authority noted that free-riding occurs in the online and offline environment and it was for Adidas to provide within its system the sufficient incentives for the distributors to invest in brand presentation and customer advice rather than to disregard customer choice. ${ }^{81}$

The GCA concluded that both intra- and inter-brand competition were restricted and the prohibition could not benefit from an exemption because there were no efficiency gains to compensate for the limitation in price competition; moreover, consumers did not benefit from it. The restraint was inefficient (as it did not solve the free-riding problem) and, in any case, less restrictive alternatives were available. ${ }^{82}$ The investigation closed in the end with Adidas making satisfactory changes to its system.

\subsection{ASICS Decision (running shoes)}

ASICS introduced a SDS in Germany, which prohibited the distributors from (i) using the ASICS' brand for online advertising, (ii) cooperating with PCTs and (iii) selling via online marketplaces.

${ }^{80}$ Ibid., p. 4. It was argued that the distributors own online shops are invisible to the customers unless they are powered by the marketplaces search engines, where the customers usually initiate their search.

81 Ibid. Additionally, an aggravating circumstance in this case was that the same technique and restrictions were imposed by other participants in the sportswear market.

82 Such as qualitative criteria applicable to marketplaces ensuring that offers of authorized distributors are recognizable. Ibid., p. 5-6. 
The GCA found in the ASICS Decision, ${ }^{83}$ the first two constraints to be hardcore restrictions of competition (limitation of sales to end usurers). They both had the effect of considerably reducing the opportunity and capacity of authorized distributors to advertise online and consequently to reach end consumers. In particular, the distributors' online offers were considerably more difficult to find, because they could not use the ASICS' brand in Internetspecific search and sale functionalities ${ }^{84}$ Furthermore, the restrictions could not be explained by TM protection considerations or effectively address free riding (which, if at all exists, was rather online than PCT-specific). The GCA also held that the Metro I criteria were not fulfilled, because the requirements were not purely qualitative in nature. ${ }^{85}$

With respect to the marketplace ban, the authority considered that it could amount to a restriction of competition by object that cannot benefit from VBER or from an individual exemption, but refrained from ultimately pronouncing on this issue. ${ }^{86}$ In reaching this preliminary conclusion, the authority employed a similar reasoning as described in the Adidas case. It was held that the restriction posed a considerable barrier to sales to end customers, affecting particularly SMEs which are dependent on being found by consumers via third party platforms. The GCA found that the ban on online sales was not indispensible in order to protect the brand image ${ }^{87}$, neither was it appropriate to address free riding. In the latter context it was for instance unclear how the ban would contribute to finance advisory services. ASICS could have instead provided financial support to aid the provision of such services, or simply require that online retailers maintain an offline store. In any case, ASICS could have imposed less drastic measures, for example by requiring that an option to limit search to authorized dealers is made available.

This decision was upheld by Bundesgerichtshof (federal supreme court for civil and criminal matters) in relation to findings on the first two restrictions

83 Decision of 26.08.2015, Case B2-98/11 (hereinafter; ASICS Decision). The summary decision is available here: https://www.bundeskartellamt.de/SharedDocs/Entscheidung/EN/ Fallberichte/Kartellverbot/2016/B2-98-11.pdf?_blob=publicationFile\&v=2 (accessed on 30.06.2018), (hereinafter; ASICS Summary Decision). For a discussion of the ASICS Decision refer to De Jong, 2016.

${ }^{84}$ I.e. use the brand in key-words in paid search engine advertisement, for the placement of advertisement on third party websites and within the context of backlinks for search engine optimisation' (ASICS Summary Decision, p. 4-5).

85 Ibid. p. 5.

86 Ibid. p. 2. The GCA deemed this question to be irrelevant since the other two restrictions have been classified as 'hardcore' and the entire system was, therefore, void.

${ }^{87}$ In fact, it considered that marketplaces do not necessarily harm product presentation or brand reputation and anyway, a manufacturer could enforce specific quality requirements based on his contractual relationship with the distributors (Ibid. p. 11). 
shortly after the Coty Germany ruling was rendered. ${ }^{88}$ The judgment received mixed comments, in particular because the Bundesgerichtshof held that the PCT ban is a hard-core restriction of sales to end-users without asking for guidance from the CJEU. Commentators note that the judgment could run counter to the logic behind Coty Germany, because the latter finds that concerns for the luxury status of a product legitimately justify limiting sales via some, but not all, on-line channels (Hazelhoff and Neuhaus, 2018). The Bundesgerichtshof discarded those doubts, since it endorsed the GCA's strict interpretation of Coty Germany, namely that it applies only to luxury goods (which, it found, ASICS products are not), (Kleine, Schaper and Lemberg, 2018).

Interestingly enough, ASICS ceased to apply the provisions that GCA has questioned before the case closed. The authority decided nonetheless to issue a declaratory decision because it would facilitate possible claims for damages in private enforcement actions.

\section{Other German Cases}

\subsection{School Bags cases}

There are two judgments concerning marketplace bans imposed in the framework of selective distribution of school bags that had opposite results (Schmidt-Kessen, 2018). ${ }^{89}$

The first was decided by the Higher Regional Court in Karlsruhe on 25 November 2009 (case 6 U 47/08 (Kart), School Bags). This judgment arose from a dispute between a distributor and a manufacturer when the latter refused to supply the contract products because the distributor was selling them on eBay, contrary to the provisions of their selective distribution agreement. The court held that the Metro I criteria were fulfilled in this case, consequently removing the selective distribution agreement from the scope of the application of competition law. The court ultimately 'came to the conclusion that the producer's interest of not having sold its goods over eBay, which had a quality-reducing 'flea market' image, outweighed distributors interest of using eBay as a convenient selling platform.' (Schmidt-Kessen, 2018, p. 308). The fact that some of the products were also traded in brick

88 Judgment of Bundesgerichtshof of 12.12.2017, Case KVZ 41/17.

${ }^{89}$ Section 2 is based in particular on the short overview of those decisions by Heinz, 2016 and Schmidt-Kessen, 2018, p. 308-309. 
and mortar discount shops did not conflict with this justification as they were only products from older collections. ${ }^{90}$

In the second judgment of 19 September 2013 (2 U 8-09 (Kart), School Backpacks and Bags), the Higher Regional Court in Berlin reached the opposite conclusion and held the contested marketplace ban to be illegal. It decided that although the Metro I criteria could have removed the SDS from the scope of the application of competition law, it failed to do so because the criteria have been applied in a discriminatory manner. '[T]he producer had sold some of the remaining stock through physical (offline) discount stores, [therefore] it could not claim that sales over eBay would harm the image of its branded products, because online and offline environment had to be treated alike to benefit from a Metro I type exemption.' (Schmidt-Kessen, 2018, p. 309). Additionally in this case, the need to protect the product image was not justified as schoolbags are not products that signal any special social status (as opposed to clothes or watches). ${ }^{91}$ In the view of the Court, the ban constituted a hardcore restriction (Article 4(b) VBER), hence could not qualify for a block exemption. ${ }^{92}$

\subsection{Functional Backpacks (Deuter)}

The case concerned the ban on selling Deuter backpacks via Amazon. The Higher Regional Court in Frankfurt in its judgment of 22 December 2015 (11 U 84/14 (Kart)) held that prohibiting distribution of high quality sports backpacks via a third party platform was justified under the Metro I criteria. In particular, it was necessary to ensure the appropriate customer service and to signal the high product quality of the backpacks (Schmidt-Kessen, 2018, p. 309). Sufficient customer service could not be provided when selling on marketplaces and was incomparable with assistance provided online and off-line within the SDS. Additionally, customers often were unaware that the products were being sold by the distributor and not Amazon. The court also

${ }^{90}$ In 2009, the Higher Regional Court in Munich in its judgement of 02.07.2009, Case U (K) $4842 / 08$, also considered an eBay ban as imposed legally because it did not amount to a general prohibition of online sales (see comments from Heinz, 2016; Seifried, 2013).

91 See comments from Seifried, 2013. See however comments regarding watches in the footnote 92 below.

92 Similarly, the Higher Regional Court in Schleswig in its judgment of 05.06.2014 in case $16 \mathrm{U}$ (Kart) 154/13 (Casio cameras) had decided that marketplace (such as Amazon) and auction sites (as eBay) bans are illegal because they foreclose the retailers from markets. Marketplaces are important for them to compete with other sellers. Justification based on the fact that cameras are a technologically complicated product and therefore require sales advice was rejected. It was, however, important in this case that Casio was not operating an SDS. See Damm, 2014; Der Betrieb portal, 2014; Heinz, 2016; Wilde Rechtsanwälte, 2014. 
noted that Deuter applied the requirement in a non-discriminatory manner as Amazon was not its authorized distributor (Seifried, 2016). The court held, however, that the PCT ban provided for by Deuter in its SDS was illegal.

\section{Dutch Nike Case}

Nike European Operations Netherlands (hereinafter; Nike) operated a selective distribution agreement, whereby Nike products were to be sold only on the sites of authorized distributors, including authorized online marketplaces such as Zalando. ${ }^{93}$ Action Sports, an authorized distributor of Nike began selling the contract products on Amazon, which was not an authorized distributor of Nike. For this reason, Nike found that Action Sport was in violation of the terms of the SDS, terminated its cooperation with Action Sport and sought a declaratory judgment confirming the legality of this decision and Nike's distribution policy.

The Dutch District Court of Amsterdam ${ }^{94}$ decided the case before Coty Germany but has relied on the opinion of Advocate General Wahl issued in Coty Germany. The court found that in the framework of the SDS, prohibiting sales of luxury goods on unauthorized online marketplaces is deemed consistent with Article 101(1) TFEU, provided certain criteria are satisfied. It then established that Nike products are luxury products and, referring to AG Wahl's opinion, held that in this case the restriction was justified in order to protect the luxury image of the products (Kmiecik, 2017). Action Sport sold the contract products on the site of an unauthorized third party, therefore it was irrelevant whether Amazon met the quality standards imposed under the SDS. Had Amazon fulfilled those criteria and wished to join Nike's SDS, Nike would have to admit Amazon based on the principle that qualitative criteria have to be applied in a non-discriminatory manner. As Kmiecik emphasized, the court did not consider the possibly of applying quantitative criteria and possible recourse to VBER (Kmiecik, 2017).

\section{French cases}

In 2007, the French Competition Authority (hereinafter; FCA) issued a decision concerning e-distribution of cosmetics and hygiene products that examined practices of several suppliers in the para-pharmaceuticals

\footnotetext{
93 For a case description and analysis, see Desmedt, 2017; Kmiecik, 2017; Ten Have, 2017.

94 Judgment of 04.10.2017, Case C/13/615474 / HA ZA 16-959, available at: https://www. recht.nl/rechtspraak/uitspraak?ecli=ECLI:NL:RBAMS:2017:7282 (accessed on 30.06.2018).
} 
sector. ${ }^{95}$ The FCA recognized in this decision that the suppliers operating SDS may prohibit sales via marketplaces in order to prevent illegal parallel trade or sales of counterfeit products and to protect product image. This authority took account of the fact that marketplaces failed to ensure that the identity of the seller is apparent to the buyer. ${ }^{96}$

In its later notice concerning E-commerce (hereinafter; the 2012 Notice) $)^{97}$, the FCA emphasized however that the above position concerning platform bans was not definitive. It stated that such restraints may amount to an illegal restriction of competition. ${ }^{98}$ This would be the case, in particular, when the marketplaces satisfy qualitative requirements, for example by creating zones (e-boutiques) reserved for authorized distributors. Jalabert-Doury notes that the latter view was reaffirmed in the FCA's decision of 23 July 2014 concerning Samsung's marketplace ban relating to the distribution of home electronics. ${ }^{99}$

More recently, Cour de cassation has revealed a tolerant approach towards marketplace bans. It annulled the decision of the Court of Appeals that rejected the request to stop the commercialization of Caudalie's cosmetics via a third party marketplace, which violated the prohibition of resale outside of SDS. ${ }^{100}$ Ferrier pointed out that the judgment indicates that a platform ban may be exempted from the prohibition of vertical restrictions (Ferrier, 2017, p. 111). This contrasts with the GCA's strict approach to marketplace bans (Blanchard, 2018, p. 20).

\section{Conclusions}

The key implications of Coty Germany and recent developments concerning e-commerce restrictions, in particular findings of the E-commerce Report, are the following.

95 Décision $n^{\circ}$ 07-D-07 du 8 mars 2007 relative à des pratiques mises en œuvre dans le secteur de la distribution des produits cosmétiques et d'hygiène corporelle, retrieved from http://www.autoritedelaconcurrence.fr/pdf/avis/07d07.pdf (accessed on 30.06.2018).

96 Ibid., para. 104.

97 Autorité de la concurrence, Avis n ${ }^{\circ} 12-\mathrm{A}-20$ du 18.9.2012 relatif au fonctionnement concurrentiel du commerce électronique, retrieved from: http://www.autoritedelaconcurrence. $\mathrm{fr} / \mathrm{pdf} / \mathrm{avis} / 12 \mathrm{a} 20$.pdf (accessed on 30.06.2018).

98 Ibid. para. 354.

99 Jalabert-Doury, 2018, p. 7. See Décision n 14-D-07 du 23 juillet 2014 relative à des pratiques mises en œuvre dans le secteur de la distribution des produits bruns, en particulier des téléviseurs, para. 181, 184, retrieved from: http://www.autoritedelaconcurrence.fr/pdf/avis/14d07. pdf (accessed on 30.06.2018).

100 Judgment of 13.09.2017, Case Caudalie c/ eNova santé no 16-15.067. 
In the first place Coty Germany affirms that it is legitimate to use selective distribution to ensure the maintenance and creation of the image of luxurious goods (provided long-established Metro conditions are met). This confirms a narrow understanding of the Pierre Fabre judgment. Moreover, under same conditions, platform bans applied in those systems do not hamper competition. In other words, selective distribution of luxury products, including when providing for marketplace bans, is not restrictive of competition at all, that is, it falls outside of the realm of Article 101 TFEU.

Second, platform bans applied in relation to other products, that is, in selective distribution of non-luxury products, may restrict competition. However, Coty Germany removed marketplace bans from the category of most serious restrictions of competition (the 'by object box'). This is because the CJEU confirmed that platform bans should not be viewed as limiting passive sales or the retailer's customer group. In this situation, platform bans for non-luxury products should be assessed based on the effects they produce, or risk to produce. Should such anticompetitive risks materialise, the SDS for non-luxury products providing for platform bans may still be considered compatible with competition law based on either individual or block exemption.

The availability of an individual exemption will most likely require demonstrating the existence of significant downstream investments (investments on the distributor level) that justifies the need for protection against free riding. Generally, it can be assumed that it will be easier to successfully argue for an individual exemption in case of platform bans used in relation to branded products and products that traditionally are considered to justify the recourse to selective distribution. By contrast, platform bans concerning products that normally do not need specialised distribution (and related significant downstream investments) are unlikely to stand the test of Article 101(3)TFEU and its national equivalents.

The law as interpreted in the light of Coty Germany, appears more flexible in case of platform bans provided for in smaller networks where the parties' market shares do not exceed $30 \%$ and so may benefit from the block exemption. The primary reason behind it is that the benefits of the block exemption are limited by market share thresholds ( $30 \%$ with some variations), rather than by the nature of the contract good. Therefore, VBER by force of presumptions upon which it is based, applies to marketplace bans introduced in relation to any product and independently of the scope of downstream investments as long as its general conditions are met. This is of course notwithstanding the possible withdrawal of the benefits of the block exemption under VBER.

In the light of the above, luxury products benefit from a privileged treatment. Limitations on sales via marketplaces in case of those products comply with 
competition law irrespectively of the supplier's or the distributors' market shares and without the need to reach for the block exemption. Suppliers of other products will need to justify the specific market definitions and the parties' market shares before they rely on VBER (or an individual exemption since there the size of market shares may influence the assessment). The special status of luxury products may be explained by assumption that those products normally require considerable investments and a specific interrelation between price-scarcity and the value of the product.

The suppliers of luxury products will, however, continue to have recourse to VBER (if market share and other conditions so permit) in cases of systems that combine quantitative and qualitative selection criteria, or when the luxury status of the product is in doubt or is difficult or time consuming to prove. The challenges concerning the determination of the status of the contract goods can be quite frequent, given the CJEU's silence on what exactly constitutes a 'luxury' good, and the fact that it has been left for the national courts to assess. The multitude of possible challenges that are likely to arise when defining what is a 'luxury' good, stand among the reasons why post-Coty diverging approaches across member states to platform bans cannot be excluded.

The above reading of Coty Germany corresponds with the Commission's views expressed in the E-commerce Report, according to which platform bans are not hardcore restrictions of competition, whereas PCT bans are. In the context of platform bans, the Commission has not made any reservations concerning the nature of the contract product. However, as discussed and illustrated by the national case law recalled earlier, a broad interpretation of Coty Germany may be questioned in some jurisdictions, in particular by the GCA.

An alternative stance is that platform bans may amount to hardcore restrictions if applied in relation to non-luxury products. The authors do not share such view, mostly because the CJEU has not justified its stance on marketplace bans by arguments related to the goods' nature. The CJEU was rather focused on the limited character of Coty's prohibition (both in terms of sales and advertisement options) and the fact that marketplaces are only one of several ways to sell online, and not even the main one (as the E-commerce Report has revealed). Furthermore, broader interpretation of Coty Germany is justified by the arguments advanced by economists.

The lesson stemming from the CJEU's approach is such that, firstly, if marketplaces are considered, they should not be combined with a restriction on sales via the distributor's own site or with restrictions on on-line advertising. In general, e-commerce related restraints should not be assessed in isolation from one another. Moreover, it is apparent from the line of reasoning employed by the CJEU, as well as the Commission in the E-commerce Report, that 
limitations akin to restrictions on advertisements, including PCTs and the use of search engines, will continue to be viewed with hostility.

Secondly, there are greater risks that anticompetitive effects are established (or the likelihood of such) in case of products that significantly depend on marketplace distribution. The latter circumstance is, again, one behind fears that approach to marketplace-related restrictions will continue to differ across the EU.

In any case, platform bans will have to be applied carefully, because the limits between an absolute ban on online sales and limitations imposed in relation to selected online channels may be difficult to define. Perhaps the upcoming review of the Vertical Guidelines will shed more light on those as well as on new issues. For instance, it will be interesting to see how the Commission will approach the emerging practice of certain marketplaces to create high-standard services dedicated to branded products.

Overall, the system established post-Coty seems to be reasonable. It privileges to certain extent luxury goods, but does not prejudge the legality of restrictions applied in relation to other goods that can broadly benefit from VBER. The system allows therefore for closer surveillance of restraints applied in relation to non-luxury products when considerable levels of market power are attained.

\section{Literature}

Adamski, M. (2017). Trybunał Sprawiedliwości UE: Coty mogło zabronić sprzedaży swoich towarów na Amazonie. Downloaded from: http://www.rp.pl/Firma/312069951-TrybunalSprawiedliwosci-UE-Coty-moglo-zabronic-sprzedazy-swoich-towarow-na-Amazonie. html (30.06.2018).

Altrogge, G. (2017). Regulierung der Digitalriesen Amazon und Facebook: Kartellamtspräsident setzt auf "unkonventionelle" Wege. Downloaded from: https://meedia.de/2017/08/18/regulierung-der-digitalriesen-amazon-und-facebookkartellamtspraesident-setzt-auf-unkonventionelle-wege/ (30.06.2018).

Bagdziński, T. (2018). Dwudziestowieczne lekarstwo na problemy XXI wieku. Glosa do wyroku TS z 6 grudnia 2017 r. w sprawie C-230/16 Coty Germany GmbH przeciwko Parfumerie Akzente GmbH. IKAR 2/7 2018.

Bernard, J. (2018). L'arrêt Coty Germany de la Cour de Justice de l'Union européenne do 6 décembre 2017. Concurrences 2/2018.

Blanchard, M. (2018). L'affaire Coty: Arrêt de principe ou arrêt d'étape? Concurrences 2/2018.

Botteman, Y., Barrio Barrio, D. (2017). The Coty Exception: A Luxury for a Selected Few? Kluwer Competition Law Blog. Downloaded from: http://competitionlawblog. kluwercompetitionlaw.com/2017/12/15/coty-exception-luxury-selected/ (30.06.2018). 
Buccirossi, P. (2015). Vertical Restraints on E-commerce and Selective Distribution, Journal of Competition Law \& Economics, 11(3), p. 747-773.

Cisnal de Ugarte, S., De Stefano, G. (2018). Selective distribution, luxury goods and online platform restrictions - the aftermath of the Coty judgment. Concurrences 2/2018. https:// www.hoganlovells.com/ /media/hogan-lovells/pdf/2018/2018_05_concurrences_2_2018_ dossier_coty.pdf?la=en (30.06.2018).

Colangelo, G. and Torti, V. (2018). Selective Distribution and Online Marketplace Restrictions under EU Competition Rules after Coty Prestige. Downloaded from: https://papers.ssrn.com/sol3/papers.cfm?abstract_id=3119129 (30.06.2018).

Damm, O. (2014). OLG Schleswig: Vertriebsverbot von Casio Europe für den Verkauf über Internethandelsplattformen ist rechtswidrig. Downloaded from: http://www. damm-legal.de/olg-schleswig-vertriebsverbot-von-casio-europe-fuer-den-verkauf-ueberinternethandelsplattformen-ist-rechtswidrig (30.06.2018).

De Jong, S. (2016). German Competition Authority Fined ASICS for Restricting Internet Sales of its Distributors. Downloaded from: https:/www.stibbe.com/en/news/2016/ february/german-competition-authority-fined-asics-for-restricting-internet-sales-of-itsdistributors (30.06.2018).

Der Betrieb portal (2014). OLG Schleswig: Kamerahersteller Casio Europe darf Vertrieb über Internetplattformen nicht ausschließen. Downloaded from: https://der-betrieb. owlit.de/document/zeitschriften/der-betrieb/2014/heft-26/wirtschaftsrecht/nachrichten/ olg-schleswig-kamerahersteller-casio-europe-d/MLX_b306? authentication=none (30.06.2018).

Desmedt, Y.N. (2017). Dutch Court Affirms Ban on Nonauthorized Online Resellers. Downloaded from: https://www.lexology.com/library/detail.aspx?g=abe28a94-f0d243fb-80d9-2ef9138e9001 (30.06.2018).

Evans, D.S. and Schmalensee, R. (2010). Failure to Launch: Critical Mass in Platform Businesses. Downloaded from: https://pdfs.semanticscholar.org/5859/ e8293f8b69e9a80905c6514dabe4064024ed.pdf (30.06.2018).

Eymard, L. and Labate, G. (2018). The ECJ judgement in Coty Germany. An economic perspective. Concurrences 2/2018.

Ezrachi, A. (2016). The Ripple Effects of Online Marketplace Bans. Downloaded from: https://ssrn.com/abstract=2868347 or http://dx.doi.org/10.2139/ssrn.2868347 (30.06.2018).

Ferrier, D. (2017). Plate-forme tierce: La Cour de cassation juge, quelques semaines après les conclusions de l'Avocat général Wahl en réponse à une question préjudicielle posée par le tribunal régional supérieur de Francfort, que l'interdiction faite à un distributeur agréé de revendre en ligne via une plate-forme tierce ne constitue pas en elle-même une restriction caractérisée (Caudalie c/ eNova santé). Concurrences 4/2017.

Greenfield, H. (2017b). Court Of Justice Of The EU Delivers Judgment In Coty Germany Case On Online Marketplace Bans. Downloaded from: http://www.ccianet. org/2017/12/court-of-justice-of-the-eu-delivers-judgment-in-coty-germany-case-ononline-marketplace-bans/ (30.06.2018).

Greenfield, H. (2017a). Advocate General At The EU Court Of Justice Issues Opinion In Coty Germany Case On Online Marketplace Bans. Downloaded from: http://www. ccianet.org/2017/07/advocate-general-at-the-eu-court-of-justice-issues-opinion-in-cotygermany-case-on-online-marketplace-bans/ (30.06.2018).

Gulcz, M. (2002). Ekonomia. Cz. I. Mikroekonomia, Poznań. 
Harvey, J. (2018). Coty: Frantically trying to catch the definition of „luxury”. Concurrences 2/2018.

Hazelhoff, A. and Neuhaus, K (2018). German Federal Court' ASICS ruling may be at odds with recent EU judgment. Downloaded from: https://cms.law/en/INT/Publication/ German-Federal-Court-s-ASICS-ruling-may-be-at-odds-with-recent-EU-judgment (30.06.2018).

Heine, K. (2012). Concept of Luxury Brands. Distinguishing Luxury Products and Brands from Similar Concepts. Downloaded from http://www.conceptofluxurybrands.com/ concept-of-luxury-brands/distinguishing-luxury-products-brands-from-similar-concepts (30.06.2018).

Heinz, S. (2016). Ban on sales via third-party internet platforms in Germany and Pierre Fabre - recent referral to the Court of Justice. Kluwer Competition Law Blog. Downloaded from http://competitionlawblog.kluwercompetitionlaw.com/2016/06/06/ ban-on-sales-via-third-party-internet-platforms-in-germany-and-the-impact-of-pierrefabre-on-selective-distribution-referral-to-the-court-of-justice-in-coty/? print $=$ print (30.06.2018).

Helfrich, M., Herweg, F. (2017). Salience in Retailing: Vertical Restraints on Internet Sales. CESifo Working Paper No. 6615 (2017). Downloaded from https://papers.ssrn. com/sol3/papers.cfm?abstract_id=3035729 (30.06.2018).

Hunter, J.S. (2017). Der Bundēeskartellamt-Chef erklart, wie er sich gegen Amazon, Facebook \& Co. durchsetzen will. Downloaded from: https://www.businessinsider. de/andreas-mundt-so-wehrt-sich-das-kartellamt-gegen-amazon-und-facebook-2017-10 (30.06.2018).

Ibáñez Colomo, P. (2017a). Case C-230/16, Coty: a straightforward issue with major implication. Downloaded from: https://chillingcompetition.com/2017/02/16/case-c23016-coty-a-straightforward-issue-with-major-implications/ (30.06.2018).

Ibanez Colomo, P. (2017b). Case C-230/16, Coty Germany GmbH: common sense prevails. Chillin'Competition blog. Downloaded from: https:/chillingcompetition.com/2017/12/06/ c\%E2\%80\%91230-16-coty-germany-gmbh-common-sense-prevails/ (30.06.2018).

Jalabert-Doury, N. (2018). Arrêt Coty: La distribution sélective solidement ancrée dans le xxie siècle. Concurrences 2/2018.

Jones, A., Surfin, B. (2016). EU Competition Law: Text, Cases and Materials, 6th Edition, Oxford.

Kleine, M., Schaper, T., Lemberg, N.H. (2018). Nach dem Coty-Urteil des EuGH: BGH konkretisiert Anforderungen für die Gestaltung selektiver Vertriebssysteme über das Internet und stärkt das Bundeskartellamt. Downloaded from: http://www. nortonrosefulbright.com/wissen/publications/163046/nach-dem-coty-urteil-des-eughbgh-konkretisiert-anforderungen-fur-die-gestaltung-selektiver-vertriebssysteme (30.06.2018).

Kmiecik, A. (2017). European Union: Dutch Court Renders Judgment On Legality of Nike's Platform Sales Restrictions. Downloaded from: http://www.mondaq. com/x/650362/Antitrust + Competition/Dutch + Court + Renders + Judgment + On + Leg ality+Of+Nikes + Platform + Sales + Restrictions (30.06.2018).

Baicoianu, M. (2013). Luxury Branding: the Difference Between Premium and Luxury Downloaded from: http://branduniq.com/2013/luxury-branding-the-difference-betweenpremium-and-luxury/ (30.06.2018). 
Monti, G. (2013). Restraints on Selective Distribution Agreements. World Competition: Law and Economics Review, 36(4), p. 489-511.

Duch-Brown, N. and Martens, B. (2015). Institute for Prospective Technological Studies. Digital Economy Working Paper 2015/17. The European Digital Single Market. Its Role in Economic Activity in the EU.

Newman, M. (2017b). Coty case over online-marketplaces ban to be heard by EU's highest court on March 30. Mlex Service. Newman M. (2017b). Podcast: Luxury goods, online marketplaces \& a heated antitrust debate. Downloaded from https://mlexmarketinsight. com/insights-center/editors-picks/antitrust/europe/luxury-brands-eu-court-win-shiftsfight-over-online-sales-bans-to-national-authorities (30.06.2018).

Roumeliotis, J.D. (2015). Luxury vs. Premium vs. Fashion: Clarifying the Disparity. Downloaded from: https://www.linkedin.com/pulse/luxury-vs-premium-fashionclarifying-disparity-james-d-roumeliotis/ (30.06.2018).

Schmidt-Kessen, M.J. (2018). Selective Distribution Systems in EU Competition and EU Trademark Law: Resolving the Tension. Journal of European Competition Law \& Practice, Volume 9, Issue 5, 1 May 2018, p. 304-316, https://doi.org/10.1093/jeclap/ lpy022 (30.06.2018).

Seifried, T. (2013). Wer Restposten verramscht, kann sein selektives Vertriebssystem gefährden: Kammergericht verbietet eBay-Verbot - KG, Urteil vom 19.09.2013 - 2 U 8/09 Kart - Andere Oberlandesgerichte entschieden anders. Downloaded from: https:// www.gewerblicherrechtsschutz.pro/blog/2013/10/wer-restposten-verramscht-kann-seinselektives-vertriebssystem-gefahrden-kammergericht-verbietet-ebay-verbot-kg-urteilvom-19-09-2013-2-u-809-kart-andere-oberlandesgerichte-entschied/ (30.06.2018).

Seifried, T. (2016). OLG Frankfurt v. 22.12.2015 - 11 U 84/14 (Kart): Amazon-Verbot für Onlinehändler bei Markenrucksäcken zulässig, Preissuchmaschinenverbot aber nicht. Downloaded from: https://www.gewerblicherrechtsschutz.pro/ blog/2016/04/amazon-verbot-fuer-onlinehandler-bei-markenrucksaecken-zulaessigpreissuchmaschinenverbot-zulaessig/ (30.06.2018).

Skibińska, E. (2018). Dystrybucja selektywna. Downloaded from http://czasopisma.beck. $\mathrm{pl} /$ monitor-prawniczy/aktualnosc/dystrybucja-selektywna/ (2018.06.30).

Temple, L.J. (1985). Selective distribution. Fordham International Law Journal, 8(1), p. 323-361.

Ten Have, F. (2017). Nike can restrict sales via online platforms within its selective distribution system. Downloaded from: https://www.stibbe.com/en/news/2017/november/ nike-can-restrict-sales-via-online-platforms-within-its-selective-distribution-system (30.06.2018).

Wilde Rechtsanwälte (2014). Press release: OLG Schleswig, 05.06.2014, 16 U Kart 154/13 (Casio): Ausschluss des Vertriebs über ebay und Maktplätze unzulässig. Downloaded from: http://www.wilde-rechtsanwaelte.de/service/handelsrecht-vertriebsrecht/urteile/ olg-schleswig-05062014-16-u-kart-15413-ausschluss-des-vertriebs-ueber-ebay-undmaktplaetze-unzulaessig/ (30.06.2018).

Vinje, T., Paemen, D. and Nourry, A. (2017). Selective Distribution Systems: CJEU Judgment in the Coty Case. Downloaded from: http://www.cliffordchance.com/ briefings/2017/12/selective_distributionsystemscjeujudgmenti.html (30.06.2018).

Whish, R. and Bailey, D. (2015). Competition Law, 8th Edition, Oxford.

Wijckmans, F. (2018). Coty Germany GmbH v Parfumerie Akzente GmbH: Possibility in Selective Distribution System to Ban Sales via Third-Party Platforms, Journal of 
European Competition Law \& Practice, Volume 9, Issue 6, 1 June 2018, Pages 373-375, https://doi.org/10.1093/jeclap/lpy015 (30.06.2018).

Petropoulos, G. (2018). Vertical restraints and e-commerce. Concurrences 1/2018.

Press Release, CMA Fines Ping 145m for Online Sales Ban on Glof Clubs, 24 August 2017. Downloaded from https://www.gov.uk/government/news/cma-fines-ping-145mfor-online-sales-ban-on-golf-clubs (30.06.2018).

Court of Justice of the European Union, Press Release No 132/17 on Coty. Downloaded from https://curia.europa.eu/jcms/upload/docs/application/pdf/2017-12/cp170132en.pdf (30.06.2018). 